\title{
29. PRELIMINARY LIPID ANALYSES OF CORES 14, 18, AND 28 FROM DEEP SEA DRILLING PROJECT HOLE 416A
}

\author{
S. C. Brassell, P. A. Comet, G. Eglinton, J. McEvoy, J. R. Maxwell, J. M. E. Quirke, and J. K. Volkman, \\ Organic Geochemistry Unit, School of Chemistry, University of Bristol, Bristol BS8 1TS, England
}

\begin{abstract}
The solvent-extractable lipids of Sections 14-4, 18-3, and 28-4 from the Valanginian turbidite sequence of Hole $416 \mathrm{~A}$ were examined. The major compound classes studied include $n$-alkanes, $n$-alkanoic acids, acyclic isoprenoid alkanes, steranes, rearranged sterenes, 4-methyl rearranged sterenes, triterpanes, triterpenes, aromatic hydrocarbons, and porphyrins. The distributions of these compounds suggest fairly uniform contributions from terrigenous, algal, and bacterial sources. Minor variations in composition may be attributed to slight changes in the relative proportions of these different sources. The lipid distributions also show that all three samples are at an immature stage of diagenesis. Comparison of constituents with those of Leg 48 black shales shows several similarities in distributions that suggest common sources. Qualitative and quantitative differences, however, exist; for example, the Leg 48 samples appear to possess a greater proportion of organic matter of bacterial origin.
\end{abstract}

\section{INTRODUCTION}

The composition and quantities of solvent-extractable lipids present in three core sections from the Valanginian turbidite sequence of Hole 416A were investigated. The aliphatic and aromatic hydrocarbons, porphyrins, and carboxylic acids were examined by chromatographic, spectroscopic, and spectrometric methods.

Table 1 summarizes the lithologic characteristics of the core sections analyzed. All three samples were shipped to the United Kingdom in a frozen state and freeze-dried at British Petroleum, Sunbury-on-Thames, prior to extraction.

This preliminary report documents the lipid composition of the extractable organic matter of each sample, and attempts to relate the composition to the environmental conditions and subsequent diagenesis and maturation. It does not include investigations of the wide range of bound lipids (e.g., hydroxy acids; Cardoso et al., 1978) or of the kerogen that composes the bulk of the organic matter.

The lipid analysis scheme was essentially similar to that used in our investigations of Leg 48 lipids (Barnes et al., in press), but differed with respect to the hydrocarbon separation to allow a discrete porphyrin fraction to be obtained. Differences are detailed in Experimental Procedures.

\section{EXPERIMENTAL PROCEDURES}

\section{General}

The measures taken to minimize contamination during sample analysis have been previously documented
(Barnes et al., in press). The instrumentation and extraction procedures were generally similar to those used for the analysis of Leg 48 samples.

The major difference in experimental procedure consisted in modification which enabled the collection of a discrete metalloporphyrin fraction. The "hydrocarbon" band obtained from preliminary TLC separation $\left(\mathrm{CH}_{2} \mathrm{Cl}_{2}\right.$ as eluant) of the total neutrals was rechromatographed using hexane/ $\mathrm{CH}_{2} \mathrm{Cl}_{2}(95: 5)$ as developer, affording alkane/alkene ( $\left.\mathrm{Rf}^{2} 0.9-1.0\right)$, aromatic (Rf 0.35-0.9), metalloporphyrin ( $\mathrm{Rf} 0.2-0.35$, pink), and polar (Rf 0.0-0.2) fractions. Analytical procedures for the alkane/alkene and aromatic cuts were similar to those for Leg 48.

In addition, an analysis of "Bestolife" pipe dope was carried out to evaluate the possibility of contamination during core recovery. Of all the oil-based lubricants used in the drilling operations, pipe dope appears to be the most prevalent contaminant; occasionally it is visible on the exterior of the sediment cores.

\section{Metalloporphyrins: Isolation and Demetallation}

Electronic spectra (uv-visible) of the fractions were obtained on a Unicam SP 800 spectrophotometer, in $\mathrm{CH}_{2} \mathrm{Cl}_{2}$, using $1 \mathrm{~cm}(600 \mu \mathrm{l}$ capacity) quartz cells. Holmium was used for calibration.

Mass spectra were obtained using a Finnigan 4000 spectrometer. The scan cycle was 2.8 seconds and the mass ranges were $\mathrm{m} / \mathrm{e} 350-550$ for the metalloporphyrin fraction from Section 416A-14-4, and m/e 350-600 for those in Sections 416A-18-3 and 416A-28-4. Operating conditions were: source temperature $250^{\circ} \mathrm{C}$, electron energy $35 \mathrm{eV}$, and emission current $400 \mu \mathrm{A}$. Samples 
TABLE 1

Samples Extracted, Hole $416 \mathrm{~A}^{\mathrm{a}}$

\begin{tabular}{|c|c|c|c|c|c|}
\hline $\begin{array}{c}\text { Sample } \\
\text { (Interval in } \mathrm{cm} \text { ) }\end{array}$ & $\begin{array}{l}\text { Sub-Bottom } \\
\text { Depth } \\
\text { (m) }\end{array}$ & Age & Lithology & $\begin{array}{l}\text { Total }^{b} \\
\text { Org. C } \\
(\%)\end{array}$ & $\begin{array}{c}\mathrm{CO}_{3}{ }^{2-} \\
(\%)\end{array}$ \\
\hline $14-4,133-150$ & 1227.9 & Valanginian & $\begin{array}{l}\text { Gray-green fissile shale containing car- } \\
\text { bonized plant remains; from turbidite } \\
\text { sequence (avg. about } 7.9 \mathrm{~cm} / \text { cycle) }\end{array}$ & 0.54 & 30.5 \\
\hline $18-3,75-91$ & 1265.8 & Valanginian & $\begin{array}{l}\text { Gray-green fissile shale containing car- } \\
\text { bonized plant remains; from turbidite } \\
\text { sequence (avg. about } 10.8 \mathrm{~cm} / \text { cycle) }\end{array}$ & 0.62 & 21.5 \\
\hline $28-4,124-145$ & 1361.8 & Valanginian & $\begin{array}{l}\text { Gray-green fissile shale containing car- } \\
\text { bonized plant remains; from turbidite } \\
\text { sequence (avg. about } 7.6 \mathrm{~cm} / \text { cycle) }\end{array}$ & 0.28 & 23.1 \\
\hline
\end{tabular}

(about $2 \mu \mathrm{g}$ ) in $\mathrm{CH}_{2} \mathrm{Cl}_{2}$ were transferred via a syringe into a clean glass crucible; a new crucible was used for each sample to prevent cross-contamination. After solvent evaporation, samples were introduced into the spectrometer by direct insertion probe. It was necessary to heat the probe slowly to allow some of the contaminants to volatilize. The porphyrins vaporized between $175^{\circ}$ and $280^{\circ} \mathrm{C}$. To avoid the effects of differential evaporation, the spectra for each mixture were averaged over the volatility range. It was necessary to perform background subtraction (using the last scan prior to the appearance of the metalloporphyrin ions above background) as considerable amounts of non-porphyrinic material were present.

Demetallation was carried out in the following manner. In each case, the crude metalioporphyrin fraction was treated with methane sulphonic acid (about $20 \mu$ l) to form a pale orange-pink solution, then heated at $108^{\circ} \mathrm{C}$ for an hour to form a purple solution. After cooling, saturated aq. $\mathrm{NaHCO}_{3}$ solution $(4 \mathrm{ml})$ was added and the mixture extracted with $\mathrm{CH}_{2} \mathrm{Cl}_{2}(2 \times 2 \mathrm{ml})$. After evaporation of $\mathrm{CH}_{2} \mathrm{Cl}_{2}$, the residue was taken up in pyridine/toluene $(1: 100,2 \mathrm{ml})$ and the solution evaporated to remove traces of water and $\mathrm{CH}_{3} \mathrm{SO}_{3} \mathrm{H}$, yielding the demetallated fraction.

HPLC analyses were carried out using a stainlesssteel column $(25 \mathrm{~cm} \times 4.6 \mathrm{~mm}$ i.d. $)$ packed with Partisil ( $5 \mu \mathrm{m}$, Whatman). The equipment consisted of two solvent delivery pumps (Waters M6000 D), solvent programer (Waters M660), and spectrophotometer (Varian Variscan L635M), equipped with Varian flow cells ( $8 \mu \mathrm{l}$ capacity) as detector, monitoring at $400 \mathrm{~nm}$. Solutions were introduced into the column via a septum inlet port using a syringe and the stop-flow technique. Gradient elution was performed with the following solvent mixtures: System A (hexane/toluene; 9:1, vol:vol) and System B (toluene/chloroform; 1:1, vol:vol). The samples were eluted using a linear gradient starting at 25 per cent $\mathrm{B}$, and reaching 75 per cent $\mathrm{B}$ after 10 minutes, and a flow rate of $1.5 \mathrm{ml} / \mathrm{min}$ at ambient temperature.

\section{RESULTS}

A blank analysis was carried out in parallel for each core section; examination of the various fractions (Table 2) by GLC revealed the absence of contaminants at concentrations corresponding to those of the sample components. The only exception was the presence of two components, one a phthalate and the other unknown, in each aromatic hydrocarbon blank (these are shown below). No porphyrins were detected by UVvisible analysis of the appropriate blank fractions.

Analysis of the "Bestolife" pipe dope confirmed that this contaminant had not made any significant contribution to the hydrocarbons and porphyrins observed.

Tentative structural assignments are mainly made on the basis of relative retention times and comparison of full mass spectra with those of authentic standards (where available), comparison with literature spectra, or spectral interpretation. In addition, co-injections of certain aromatic hydrocarbon components were carried out (as shown below). The polar neutral fractions, including ketones and alcohols, have not yet been examined.

\section{Aliphatic Hydrocarbons (Alkane/Alkene) \\ Normal}

The major class of component of all three samples is $n$-alkane, dominated in each case by $n-\mathrm{C}_{27}$. The relative proportions of the individual carbon number members, calculated from $\mathrm{m} / \mathrm{e} 85$ mass fragmentograms, are shown schematically in Figure 1; the absolute concentration of specific $n$-alkanes given is in Table 2 .

The carbon preference index (CPI) values for the $\mathrm{C}_{14}$ to $\mathrm{C}_{21}$ range are $1.6,1.2$, and 1.5 for Sections $416 \mathrm{~A}-14-4,18-3$, and $28-4$, respectively. These values are much lower than the corresponding CPI values for the $C_{22}$ to $C_{35}$ range, which are 2.6, 2.4, and 2.8.

\section{Branched/Cyclic}

The acyclic isoprenoid alkanes recognized in each core section include $\mathrm{C}_{16}$ and $\mathrm{C}_{18}-\mathrm{C}_{21}$ members identified 

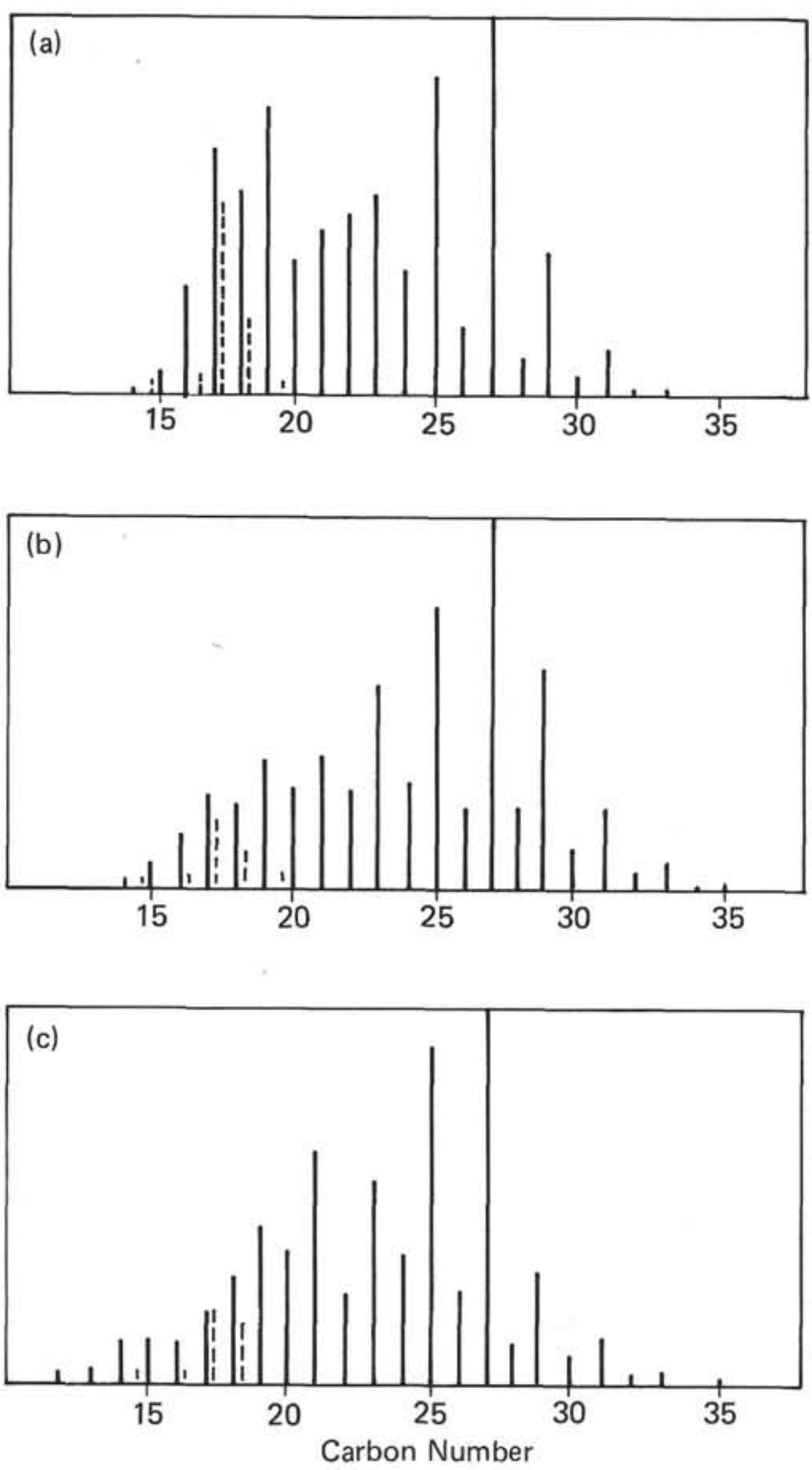

Figure 1. Relative concentrations of n-alkanes (unbroken lines) and acyclic isoprenoid alkanes (broken lines; from left to right, $C_{16}, C_{18}, C_{19}, C_{20}, C_{21}$ ) in Sections: (a) $416 A-14-4$, (b) $416 A-18-3$, (c) $416 A-$ 28-4.

by gas-chromatograph retention times and mass spectrometry. The distributions are given in Figure 1, as calculated from $\mathrm{m} / \mathrm{e} 85$ mass fragmentography.

The polycyclic isoprenoid hydrocarbons identified in all three core sections include series of rearranged sterenes (shown by mass fragmentography of $\mathrm{m} / \mathrm{e} 257$, Figure 2) and 4-methyl rearranged sterenes (m/e 271, Figure 2). The components present in all three samples (quantitated in Tables 3 and 4) are similar, although the relative concentrations of series members in Sections 416A-14-4 and 416A-18-3 differ slightly from those of Section 416A-28-4. In the quantitation of both rearranged sterenes and their 4-methyl analogs, the liability of these compounds makes rapid analysis imperative.
Even within the few days between extraction and GCMS analysis, a proportion of these compounds undergoes oxidation, thereby influencing the absolute amounts observed. In future analyses, we hope to retard this oxidation process by the introduction of radical inhibitors. Mass fragmentographic searches for rearranged steranes $(\mathrm{m} / \mathrm{e} 259)$ and 4-methyl rearranged steranes $(\mathrm{m} / \mathrm{e}$ 273) indicated the absence of these compounds in significant quantities.

The sterane $(\mathrm{m} / \mathrm{e} 217$, Figure $3 \mathrm{~A})$ content of the shallower core sections (Table 5A) is considerably greater than that of Section 416A-28-4, whereas sterenes (m/e 215, Figure 3B) are only present above trace quantities $(0.5 \mathrm{ng} / \mathrm{g}$ per major component) in Section 416A-18-3 (Table 5B). Mass fragmentography of m/e 253 indicates the presence of a series of mono-aromatic steroidal compounds in all three samples. In addition, mass fragmentography of m/e 239 and 267 suggested that parallel series of methyl and normethyl monoaromatic steroids might also be present in each of the samples.

The same triterpanes and triterpenes (m/e 191, Figure 4) are present in all three samples, although the relative concentrations of the individual components in Section 416A-28-4 differ markedly from those of Sections 14-4 and 18-3 (Table 6). All the triterpenoid hydrocarbons recognized possess hopanoid skeletons with 5rather than 6-membered E-rings. The absence of diterpenes and diterpanes was shown by mass fragmentography of $\mathrm{m} / \mathrm{e} 189$ and $\mathrm{m} / \mathrm{e} 191$, because no significant response was observed for all three samples in the $n-\mathrm{C}_{17}$ to $n$ - $\mathrm{C}_{24}$ alkane GC elution region.

\section{Aromatic Hydrocarbons}

Identification of polycyclic aromatic hydrocarbon (PAH) components was made on the basis of mass spectral characteristics and gas chromatographic retention times. Several assignments were confirmed by gaschromatograph co-injection with standards on glass capillary columns (Figure 5). The quantities of the individual PAH detected in each of the three samples are listed in Table 7, together with the mass spectrometric ions used for their recognition. The PAH compositions of the three core sections closely resemble one another, both qualitatively and quantitatively. Perylene is the major single component in all three samples. A substantial number of the PAH recognized possess alkyl substituents; these alkyl homologs are often present in greater quantity than their unsubstituted counterparts.

\section{Porphyrins}

No demetallated porphyrins were detected in the sediment extracts, as indicated by the absence of a redbrown band $(\mathrm{Rf}<0.8)$ in the initial TLC separation, and confirmed by the absence of bands fluorescing red under ultra-violet light $(\lambda 254 \mathrm{~nm})$. Vanadyl porphyrins also were not detected, as shown by the absence of a red band $(\mathrm{Rf}<0.8)$ in the initial TLC separation.

The UV-visible data for the metalloporphyrins are summarized in Table 8 . These show that the metallopor- 
TABLE 2

Lipid Analyses, Hole 416A

\begin{tabular}{|c|c|c|c|c|c|c|c|}
\hline \multirow[b]{2}{*}{ Component Classes $^{\mathrm{a}}$} & \multirow[b]{2}{*}{ Structural Type } & \multicolumn{2}{|c|}{ Data Reported } & \multirow[b]{2}{*}{ Example (Structure) } & \multicolumn{3}{|c|}{$\begin{array}{c}\text { Concentration in } \\
\text { Core Sections }{ }^{\mathrm{b}} \\
\text { (ng/g) }\end{array}$} \\
\hline & & Table & Figure & & $14-4$ & $18-3$ & $28-4$ \\
\hline \multicolumn{8}{|l|}{ Aliphatic hydrocarbons } \\
\hline$n$-alkane & Straight chain & - & 1 & $n-\mathrm{C}_{27}$ & 43 & 70 & 43 \\
\hline Acyclic isoprenoid & Branched chain & - & 1 & Pristane & 22 & 14 & 8 \\
\hline Diterpane & Diterpenoid & - & - & - & $-\mathrm{c}$ & - & - \\
\hline Diterpene & Diterpenoid & - & - & - & - & - & - \\
\hline Triterpane (hopanoid) & Triterpenoid & 6 & 4 & Homohopane (VII, $\left.\mathrm{R}=\mathrm{CH}\left(\mathrm{CH}_{3}\right) \mathrm{C}_{2} \mathrm{H}_{5}\right)$ & 27 & 12 & 10 \\
\hline Triterpene (hopanoid) & Triterpenoid & 6 & 4 & $\begin{array}{l}\text { 22,29,30-trisnorneohop-13(18)-ene } \\
\text { (IV, R=H) }\end{array}$ & 5 & 1 & 4 \\
\hline Triterpene (non-hopanoid) & Triterpenoid & - & - & - & - & - & - \\
\hline Neohopane & Triterpenoid & - & - & - & - & - & - \\
\hline Sterane & Steroid & $5 \mathrm{~A}$ & 3 & $\mathrm{C}_{29}{ }^{\mathrm{H}_{52}}\left(\mathrm{II}, \mathrm{R}=\mathrm{C}_{2} \mathrm{H}_{5}\right)$ & 1.5 & 3.0 & 1.5 \\
\hline Sterene & Steroid & $5 B$ & 3 & $\mathrm{C}_{29} \mathrm{H}_{50}\left(\mathrm{III}, \mathrm{R}=\mathrm{C}_{2} \mathrm{H}_{5}\right)$ & $\operatorname{Tr}$ & 3.5 & $\operatorname{Tr}$ \\
\hline Rearranged sterane & Steroid & & & $\mathrm{C}_{29} \mathrm{H}_{52}$ & - & - & - \\
\hline Rearranged sterene & Steroid & 3 & 2 & $\mathrm{C}_{29} \mathrm{H}_{50}\left(\mathrm{I}, \mathrm{R}=\mathrm{C}_{2} \mathrm{H}_{5}, \mathrm{R}^{\prime}=\mathrm{H}\right)$ & 31 & 35 & 22 \\
\hline 4-Me sterane & Steroid & - & - & $\mathrm{C}_{30} \mathrm{H}_{54}$ & - & - & - \\
\hline 4-Me sterene & Steroid & - & - & $\mathrm{C}_{30} \mathrm{H}_{52}$ & - & - & - \\
\hline 4-Me rearranged sterene & Steroid & 4 & 2 & $\mathrm{C}_{30} \mathrm{H}_{52}\left(\mathrm{I}, \mathrm{R}=\mathrm{C}_{2} \mathrm{H}_{5}, \mathrm{R}^{\prime}=\mathrm{CH}_{3}\right)$ & 4.5 & 4.5 & 7.5 \\
\hline \multicolumn{8}{|l|}{ Aromatic hydrocarbons } \\
\hline Unsubstituted PAH & PAH & 7 & 5 & Phenanthrene $(\mathrm{X})$ & 1 & 0.5 & 0.5 \\
\hline Unsubstituted PAH & PAH & 7 & 5 & Perylene (XXVI) & 4 & 5 & 2.5 \\
\hline Alkyl substituted PAH & Alkyl PAH & 7 & 5 & $\begin{array}{l}\text { Alkyl Phenanthrenes }\left(\mathrm{XI}, \mathrm{R}=\mathrm{CH}_{3} \text {, }\right. \\
\left.\mathrm{C}_{2} \mathrm{H}_{5}, \mathrm{C}_{3} \mathrm{H}_{7}\right)\end{array}$ & 5.5 & 12 & 5 \\
\hline Aromatized triterpene & Triterpenoid & 7 & 5 & $\begin{array}{l}\text { Tri- and tetra-aromatic hopanoid } \\
\left(\mathrm{XXIX}, \mathrm{XXX}, \mathrm{XXXI}, \mathrm{R}=\mathrm{CH}_{3}\right)\end{array}$ & 4 & 4 & 1 \\
\hline Aromatic steroid & Steroid & - & - & $\mathrm{C}_{27} \mathrm{H}_{44}$ & 5 & 14 & 9 \\
\hline \multicolumn{8}{|l|}{ Carboxylic acids } \\
\hline$n$-alkanoic & Straight chain & 10 & 7 & $16: 0$ & 2.5 & 5.0 & $\operatorname{Tr}$ \\
\hline$n$-alkenoic & Straight chain & - & 7 & $16: 1$ & - & 0.5 & - \\
\hline Monomethyl branched & Branched chain & - & - & Iso- $15: 0+$ anteiso $15: 1$ & $\operatorname{Tr}$ & 0.5 & $\operatorname{Tr}$ \\
\hline Acyclic isoprenoid & Branched chain & - & - & Phytanic & $\operatorname{Tr}$ & $\operatorname{Tr}$ & $\operatorname{Tr}$ \\
\hline Diterpene & Diterpenoid & - & - & Dehydroabietic & - & - & $\operatorname{Tr}$ \\
\hline Triterpene & Triterpenoid & - & - & - & - & - & $\operatorname{Tr}$ \\
\hline Hydroxylated & Straight chain & - & - & - & n.d. & n.d. & n.d. \\
\hline \multicolumn{8}{|l|}{ Metalloporphyrins } \\
\hline Ni DPEP & Metalloporphyrin & 8,9 & 6 & 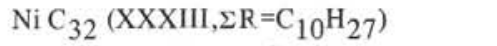 & 35 & 31 & n.d. \\
\hline Ni etio & Metalloporphyrin & 8,9 & 6 & $\mathrm{NiC}_{30}\left(\mathrm{XXXI1}, \Sigma \mathrm{R}=\mathrm{C}_{10} \mathrm{H}_{28}\right)$ & 2.5 & 7 & n.d. \\
\hline VO porphyrins & Metalloporphyrin & - & - & - & - & - & - \\
\hline Cu porphyrins & Metalloporphyrin & - & - & - & - & - & - \\
\hline \multicolumn{8}{|l|}{ Chlorins } \\
\hline Chlorins & Chlorin & - & - & - & - & - & - \\
\hline
\end{tabular}

Note: $\operatorname{Tr}=$ trace of component $(<0.5 \mathrm{ng} / \mathrm{g}$ dry wt. sediment $)$; .d. $=$ not determined.

${ }_{\mathrm{b}}^{\mathrm{a}} \mathrm{TLC}$ fractions and appropriate compound classes therein. The various polar fractions are not listed since they have not yet been studied.

Dry weight sediment, quantitated from GLC and/or mass fragmentography or HPLC to nearest $0.5 \mathrm{ng} / \mathrm{g}$.

${ }^{\mathrm{c}}$ Not observed.

phyrins are nickel complexes. The lack of absorption at $520,530,560$, and $570 \mathrm{~nm}$ in all three samples indicates that copper and vanadyl porphyrins are not present in detectable amounts. The ratio of the $\alpha(550 \mathrm{~nm})$ to $\beta$
(514 nm) absorptions ranges from 2.3 to 2.4 , indicating that etioporphyrins compose 30 to 40 per cent of the total porphyrins, by comparison with the $\alpha / \beta$ ratios of nickel etioporphyrin-I (3.0, Buchler and Puppe, 1970), 

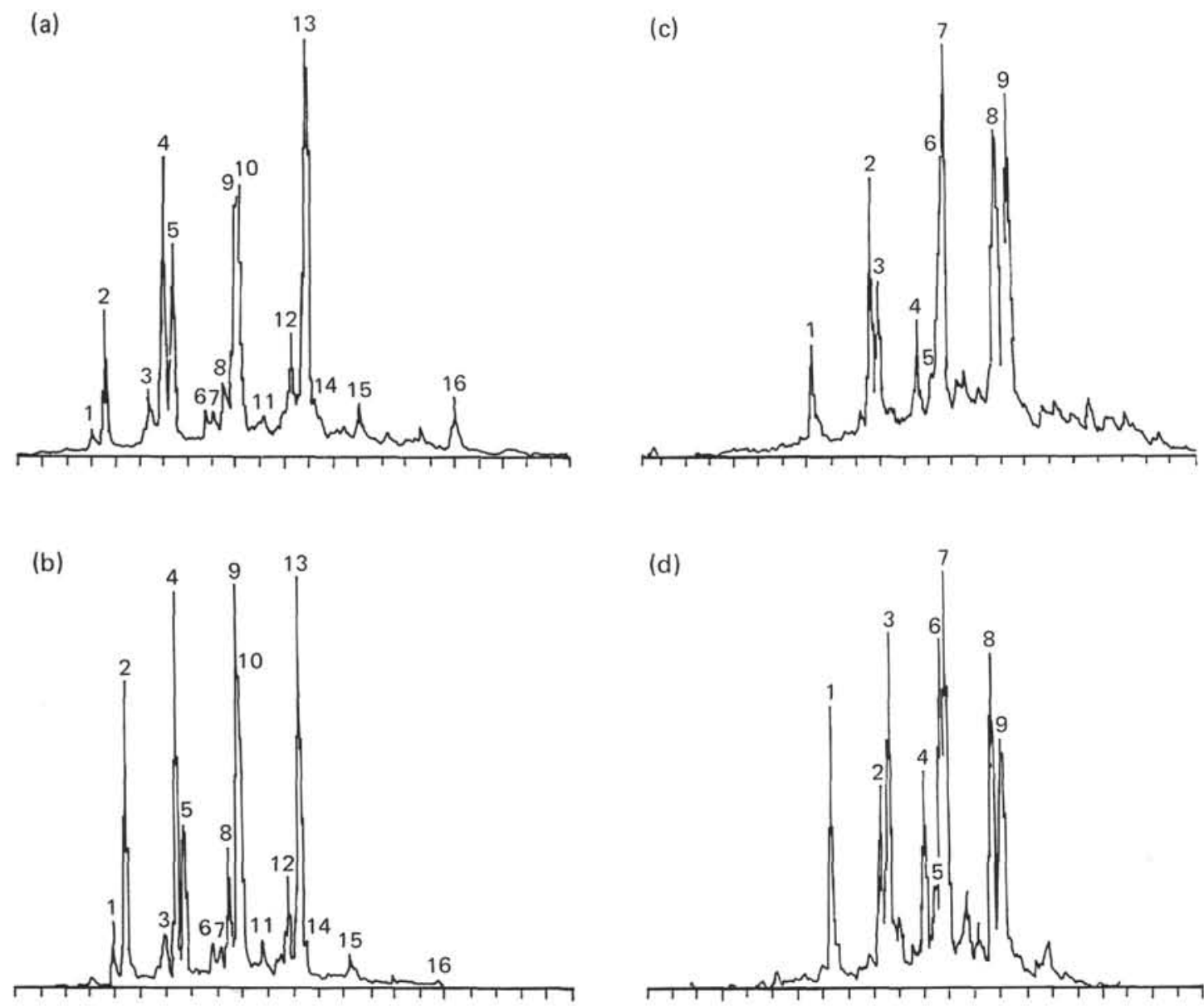

Figure 2. Partial mass fragmentograms of $m / e 257(a, \times 3.5$ and $b, \times 5.4)$ and $m / e 271$ (c, $\times 14.1$ and $d, \times 16.1)$ from $C-G C-M S$ analysis of aliphatic-hydrocarbon fractions from Sections 416A-18-3 ( $a$ and $c$ ) and 416A-28-4 (b and d). Peak numbers refer to Tables 3 and 4 , respectively. The mass-fragmentogram multiplication factors normalize (to $100 \%$ ) the ion current for the scan with the highest signal. The factors are therefore inversely proportional to the absolute concentrations.

and nickel deoxophylloerythroetioporphyrin (2.0, Baker et al., 1978); however, changes in $\beta$ substitution (e.g., replacing alkyl groups with hydrogens) may significantly alter $\alpha / \beta$ ratios.

The nickel petroporphyrin distributions were assessed from the averaged, background-subtracted mass spectra. The range of DPEP porphyrins varies from $\mathrm{C}_{29}$ to $C_{32}$ (416A-14-4) to $C_{26}$ to $C_{32}$ (416A-18-3 and 28-4), and of etioporphyrins from $\mathrm{C}_{26}$ to $\mathrm{C}_{30}$ to $\mathrm{C}_{26}$ to $\mathrm{C}_{29}$ in Sections 416A-18-3 and 416A-28-4, respectively. No etioporphyrins were recognized in Section 416A-14-4. In all three samples, the major nickel porphyrin component is $\mathrm{C}_{32}$ DPEP. We did not attempt more detailed and quantitative interpretation because of the small sample size and the high background of non-porphyrinic material; indeed, the relative intensity of the $\mathrm{M}^{+}$and associated isotopic ions did not accord well with those observed for nickel petroporphyrin standards.

HPLC analysis (HajIbrahim et al., 1978) of the demetallated petroporphyrins enabled tentative assignment of individual components by co-injection with etioporphyrin-I and the individual $\mathrm{C}_{30}$ and $\mathrm{C}_{31}$ etio and
$\mathrm{C}_{31}$ DPEP petroporphyrins isolated from gilsonite, an Eocene bitumen from the Uinta Basin, Utah.

The HPLC distributions of Sections 416A-14-4 and 18-3 were similar (Figure 6) and resembles the distribution of the demetallated porphyrins of gilsonite. Peak assignments (Figure 6 and Table 9) are based on the known components of gilsonite (Quirke et al., unpublished results; HajIbrahim, 1978). The DPEP/etio ratio calculated from the HPLC peak areas is about 2.0 for both core sections. There was insufficient petroporphyrin in Section 416A-28-4 to allow HPLC analysis.

\section{Carboxylic Acids (FAME)}

Monocarboxylic acids were very minor components (Table 10) of the three core sections. Straight-chain components predominated in each case; however, different molecular distributions were found in each sample. The relative concentrations of the straight-chain monocarboxylic acids are shown in Figure 7.

The top section (416A-14-4) exhibited a bimodal distribution from $C_{12}$ to $C_{32}$, maximizing at $18: 0$, with a strong secondary maximum at 28:0. The distribution of 
TABLE 3

Rearranged Sterenes, Hole 416A

\begin{tabular}{|c|c|c|c|c|c|c|}
\hline \multirow[b]{2}{*}{ Peak $^{a}$} & \multirow[b]{2}{*}{ Formula } & \multirow{2}{*}{$\begin{array}{l}\text { Structure }^{b} \\
R\left(R^{\prime}=H\right)\end{array}$} & \multirow[b]{2}{*}{ Mol. Wt. } & \multicolumn{3}{|c|}{$\begin{array}{c}\text { Concentration in } \\
\text { Core Sections }{ }^{\mathrm{c}} \\
(\mathrm{ng} / \mathrm{g})\end{array}$} \\
\hline & & & & $14-4$ & $18-3$ & $28-4$ \\
\hline 1 & $\mathrm{C}_{27} \mathrm{H}_{46}$ & $\mathrm{I}, \mathrm{H}$ & 370 & 1.0 & 1.7 & 3.4 \\
\hline 2 & $\mathrm{C}_{27} \mathrm{H}_{46}$ & $\mathrm{I}, \mathrm{H}$ & 370 & 5.8 & 11.7 & 16.3 \\
\hline 3 & $\mathrm{C}_{27} \mathrm{H}_{46}$ & I, H & 370 & 3.3 & 3.5 & 2.2 \\
\hline 4 & $\mathrm{C}_{27} \mathrm{H}_{46}$ & $\mathrm{I}, \mathrm{H}$ & 370 & 23.5 & 23.9 & 20.7 \\
\hline 5 & $\mathrm{C}_{28} \mathrm{H}_{48}$ & $\mathrm{I}, \mathrm{CH}_{3}$ & 384 & 11.6 & 18.0 & 7.3 \\
\hline 6 & $\mathrm{C}_{28} \mathrm{H}_{48}$ & $\mathrm{I}, \mathrm{CH}_{3}$ & 384 & 1.4 & 1.6 & 1.2 \\
\hline 7 & $\mathrm{C}_{28} \mathrm{H}_{48}$ & $\mathrm{I}, \mathrm{CH}_{3}$ & 384 & 1.2 & 1.2 & 1.2 \\
\hline 8 & $\mathrm{C}_{28} \mathrm{H}_{48}$ & $\mathrm{I}, \mathrm{CH}_{3}$ & 384 & 1.9 & 3.1 & 6.6 \\
\hline 9 & $\mathrm{C}_{29} \mathrm{H}_{50}$ & $\mathrm{I}, \mathrm{C}_{2} \mathrm{H}_{5}$ & $398\}$ & & $\{11.1\}$ & \\
\hline 10 & $\mathrm{C}_{28} \mathrm{H}_{48}$ & $\mathrm{I}, \mathrm{CH}_{3}$ & 384 & 18.2 & $\{10.8\}$ & 21.0 \\
\hline 11 & $\mathrm{C}_{28} \mathrm{H}_{48}$ & $\mathrm{I}, \mathrm{CH}_{3}$ & 384 & 2.4 & 2.0 & 1.5 \\
\hline 12 & $\mathrm{C}_{29} \mathrm{H}_{50}$ & $\mathrm{I}, \mathrm{C}_{2} \mathrm{H}_{5}$ & 398 & 7.2 & 8.1 & 5.5 \\
\hline 13 & $\mathrm{C}_{29} \mathrm{H}_{50}$ & $\mathrm{I}, \mathrm{C}_{2} \mathrm{H}_{5}$ & 398 & 30.9 & 35.2 & 21.8 \\
\hline 14 & $\mathrm{C}_{29} \mathrm{H}_{50}$ & $\mathrm{I}, \mathrm{C}_{2} \mathrm{H}_{5}$ & 398 & 0.9 & 1.4 & $\operatorname{Tr}$ \\
\hline 15 & $\mathrm{C}_{30} \mathrm{H}_{52}$ & $\mathrm{I}, \mathrm{C}_{3} \mathrm{H}_{7} ?$ & 412 & 2.6 & 3.6 & 1.3 \\
\hline 16 & $\mathrm{C}_{29} \mathrm{H}_{50}$ & $\mathrm{I}, \mathrm{C}_{2} \mathrm{H}_{5}$ & 398 & 2.9 & 4.4 & $\operatorname{Tr}$ \\
\hline
\end{tabular}

Note: $\operatorname{Tr}=$ trace of component $(<0.5 \mathrm{ng} / \mathrm{g}$ dry wt. sediment $)$. apeak designations of Figure $2 \mathrm{a}, 2 \mathrm{~b}$.

${ }^{b}$ General structure; $C-20$ stereochemistry not determined and individual peaks not assigned to this or other isomers (see text). Structures shown in Appendix, this chapter.

${ }^{\mathrm{c}}$ Dry wt. sediment, quantitated from mass fragmentography of $\mathrm{m} / \mathrm{e} 257$

TABLE 4

4-Methyl Rearranged Sterenes, Hole 416A

\begin{tabular}{|c|c|c|c|c|c|c|}
\hline \multirow[b]{2}{*}{ Peak $^{a}$} & \multirow[b]{2}{*}{ Formula } & \multirow{2}{*}{$\begin{array}{l}\text { Structure }{ }^{b}, \\
R\left(R^{\prime}=\mathrm{CH}_{3}\right)\end{array}$} & \multirow[b]{2}{*}{ Mol. Wt. } & \multicolumn{3}{|c|}{$\begin{array}{l}\text { Concentration in Core } \\
\text { Sectionc }^{c}(\mathrm{ng} / \mathrm{g})\end{array}$} \\
\hline & & & & 144 & $18-3$ & $28-4$ \\
\hline 1 & $\mathrm{C}_{28} \mathrm{H}_{48}$ & $\mathrm{I}, \mathrm{H}$ & 384 & 0.9 & 1.6 & 6.4 \\
\hline 2 & $\mathrm{C}_{28} \mathrm{H}_{48}$ & $1, \mathrm{H}$ & 384 & 3.7 & 4.3 & 4.6 \\
\hline 3 & $\mathrm{C}_{29} \mathrm{H}_{50}$ & $1, \mathrm{CH}_{3}$ & 398 & 1.8 & 1.8 & 7.9 \\
\hline 4 & $\mathrm{C}_{30} \mathrm{H}_{52}$ & $\mathrm{I}, \mathrm{C}_{2} \mathrm{H}_{5}$ & 412 & 1.1 & 1.7 & 4.7 \\
\hline 5 & $\mathrm{C}_{29} \mathrm{H}_{50}$ & $\mathrm{I}, \mathrm{CH}_{3}$ & 398 & $\operatorname{Tr}$ & $\mathrm{Tr}$ & 0.9 \\
\hline 6 & $\mathrm{C}_{30} \mathrm{H}_{52}$ & $\mathrm{I}, \mathrm{C}_{2} \mathrm{H}_{5}$ & $412\}$ & \multirow{2}{*}{5.2} & \multirow[b]{2}{*}{6.6} & 3.4 \\
\hline 7 & $\mathrm{C}_{29} \mathrm{H}_{50}$ & $\mathrm{I}, \mathrm{CH}_{3}$ & $398\}$ & & & $\{10.1$ \\
\hline 8 & $\mathrm{C}_{30} \mathrm{H}_{52}$ & $1, \mathrm{C}_{2} \mathrm{H}_{5}$ & $412^{\prime}$ & 4.5 & 4.6 & 7.5 \\
\hline 9 & $\mathrm{C}_{30} \mathrm{H}_{52}$ & $\mathrm{I}, \mathrm{C}_{2} \mathrm{H}_{5}$ & 412 & 3.6 & 5.1 & 5.4 \\
\hline
\end{tabular}

Note: $\mathrm{Tr}=$ trace of component $(<0.5 \mathrm{ng} / \mathrm{g}$ dry wt. sediment $)$.

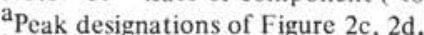

${ }^{b}$ General structure; C-20 stereochemistry not determined and individual peaks not assigned to this or other isomers (see text). Structures shown in Appendix, this chapter.

cDry wt. sediment, quantitated from mass fragmentography of $\mathrm{m} / \mathrm{e}$ 271.

long straight-chain acids is typical of higher plants (Eglinton and Hamilton, 1967), whereas the shorter chain acids are thought to reflect both a bacterial and algal origin. Only trace quantities of iso- and anteisobranched acids, often abundant in gram-positive bac-
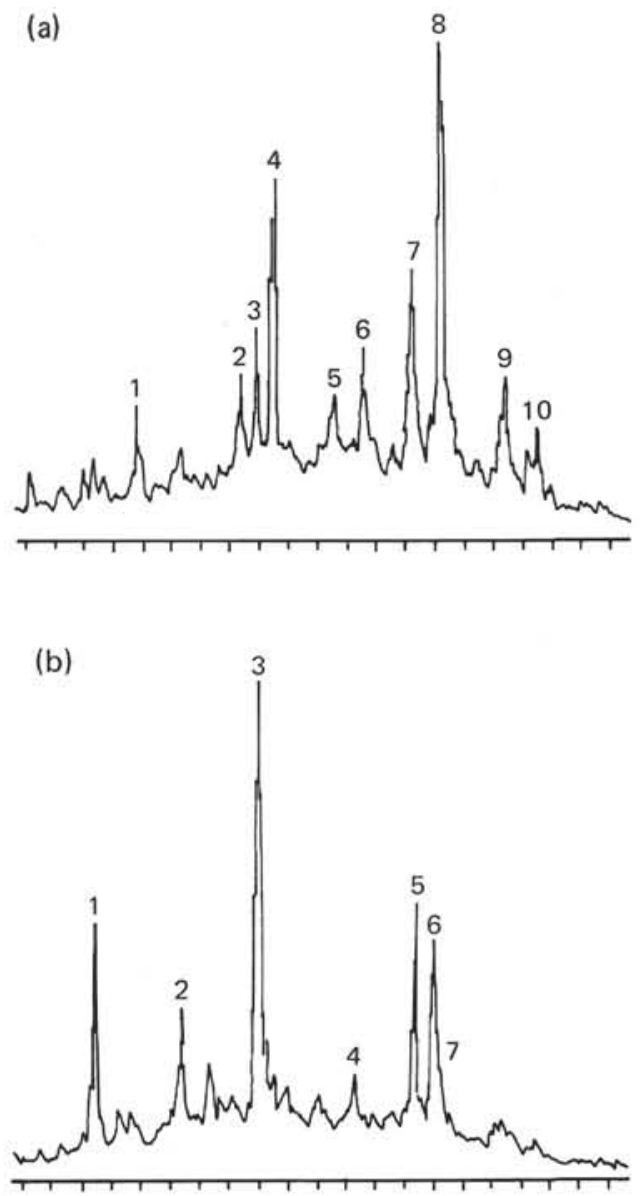

Figure 3. Partial mass fragmentograms of $\mathrm{m} / \mathrm{e} 217$ (a, $\times 36.3)$ and $m / e 215(b, \times 30.8)$ for the aliphatichydrocarbon fraction of Section 416A-18-3. (Identical scan ranges are shown.) Peak numbers refer to Tables $5 A$ and $5 B$, respectively.

teria (Shaw, 1974) were detected. Triterpanoic acids and unsaturated straight-chain acids were below the level of detection.

The middle section (416A-18-3) showed an unusual distribution $\left(\mathrm{C}_{12}\right.$ to $\left.\mathrm{C}_{28}\right)$, long-chain $n$-fatty acids representing less than 2.per cent of those present. A strong predominance of 16:0,14:0, and 12:0 was found, in contrast to Section 416A-14-4, where 18:0 predominated. Iso- and anteiso- 15:0 (ratio 1.7:1, 1.6\% of monocarboxylic acids) were also present, suggesting a slightly larger bacterial contribution. However, no triterpanoic acids of the hopane type could be detected. Small quantities of $16: 1(4.7 \%)$ and $18: 1(4.5 \%)$ were detected, together with 18:2 $(2.8 \%)$ identified from full mass spectra and co-injection on capillary OV-1 and Carbowax GC columns. This is the only sample in which unsaturated monocarboxylic acids could be detected.

The concentration of monocarboxylic acids in the deepest section (416A-28-4) is less than 7 per cent of the concentrations in the overlying samples. The bimodal distribution, similar to that for Section 416A-14-4, 
TABLE 5A

Steranes, Hole 416A

\begin{tabular}{ccccccc}
\hline & & & \multicolumn{4}{c}{$\begin{array}{c}\text { Concentration in Core } \\
\text { Sectionc }\end{array}$ (ng/g) } \\
Peak $^{\mathrm{a}}$ & Formula & $\begin{array}{c}\text { Structure } \\
\text { R }\end{array}$ & Mol. Wt. & $14-4$ & $18-3$ & $28-4$ \\
\hline 1 & $\mathrm{C}_{27} \mathrm{H}_{48}$ & II, H & 372 & $\mathrm{Tr}$ & 0.7 & $\mathrm{Tr}$ \\
2 & $\mathrm{C}_{27} \mathrm{H}_{48}$ & II, H & 372 & 0.3 & 0.6 & $\mathrm{Tr}$ \\
3 & $?$ & $?$ & $?$ & 0.5 & 0.9 & $\mathrm{Tr}$ \\
4 & $\mathrm{C}_{27} \mathrm{H}_{48}$ & II, H & 372 & 1.2 & 1.9 & 0.4 \\
5 & $\mathrm{C}_{28} \mathrm{H}_{50}$ & II, $\mathrm{CH}_{3}$ & 386 & 0.2 & 0.4 & $\mathrm{Tr}$ \\
6 & $\mathrm{C}_{28} \mathrm{H}_{50}$ & II, $\mathrm{CH}_{3}$ & 386 & 0.5 & 0.7 & 0.2 \\
7 & $\mathrm{C}_{29} \mathrm{H}_{52}$ & II, $\mathrm{C}_{2} \mathrm{H}_{5}$ & 400 & 0.6 & 1.4 & 0.4 \\
8 & $\mathrm{C}_{29} \mathrm{H}_{52}$ & II, $\mathrm{C}_{2} \mathrm{H}_{5}$ & 400 & 1.4 & 2.9 & 0.6 \\
9 & $?$ & $?$ & $?$ & 0.3 & 0.7 & 0.4 \\
10 & $?$ & $?$ & $?$ & $\mathrm{Tr}$ & 0.6 & 0.2 \\
\hline
\end{tabular}

Note: $\mathrm{Tr}=$ trace quantity $(<0.1 \mathrm{ng} / \mathrm{g}$ dry wt, sediment $)$.

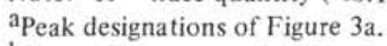

${ }^{b}$ General structures; individual peaks not assigned to this or other isomers shown in Appendix, this chapter.

${ }^{c}$ Dry wt. sediment, quantitation from mass fragmentography of $\mathrm{m} / \mathrm{e}$ 217.

TABLE 5B

Sterenes in Section 416A-18-3 ${ }^{\mathrm{a}}$

\begin{tabular}{ccccc}
\hline Peak $^{\text {b }}$ & Formula & $\begin{array}{c}\text { Structure } \\
\text { R }\end{array}$ & Mol. Wt. & $\begin{array}{c}\text { Concentration } \\
\text { (ng/g) }\end{array}$ \\
\hline 1 & $\mathrm{C}_{27} \mathrm{H}_{46}$ & III, H & 370 & 1.7 \\
2 & $\mathrm{C}_{28} \mathrm{H}_{48}$ & III, $\mathrm{CH}_{3}$ & 384 & 0.9 \\
3 & $\mathrm{C}_{29} \mathrm{H}_{50}$ & III, $\mathrm{C}_{2} \mathrm{H}_{5}$ & 398 & 3.6 \\
4 & $?$ & $?$ & $?$ & 0.3 \\
5 & $?$ & $?$ & $?$ & 1.8 \\
6 & $\mathrm{C}_{29} \mathrm{H}_{50}$ & III, $\mathrm{C}_{2} \mathrm{H}_{5}$ & 398 & 1.5 \\
7 & $\mathrm{C}_{29} \mathrm{H}_{50}$ & III, $\mathrm{C}_{2} \mathrm{H}_{5}$ & 398 & 0.1 \\
\hline
\end{tabular}

${ }^{\mathrm{a}}$ Sterenes present in Sections $416 \mathrm{~A}-14-4$ and $28-4$ in trace quantities $(<0.5 \mathrm{ng} / \mathrm{g}$ dry wt. sediment).

$\mathrm{b}$ Peak designations of Figure $3 \mathrm{~b}$.

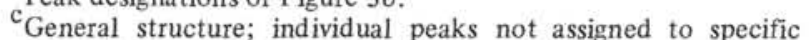
double-bond positions. Structures shown in Appendix, this chapter.

${ }^{d}$ Dry wt. sediment, quantitation from mass fragmentography of $\mathrm{m} / \mathrm{e} 215$.

ranges from $\mathrm{C}_{10}$ to $\mathrm{C}_{32}$, maximizing at $16: 0$. No unsaturated monocarboxylic acids were detected and only small quantities of iso- and anteiso- 15:0 (ratio 1:1.4, $3 \%$ of monocarboxylic acids) were found. Several triterpanoid acids of the hopane type were detected from the mass chromatogram for $\mathrm{m} / \mathrm{e} 191$; however, the quantities present were too small $\left(<10^{-2} \mathrm{ng} / \mathrm{g}\right)$ for detailed structural analysis.

Isoprenoid acids were minor components in all three core sections, a relative enhancement being found in the deepest section. Diterpenoid acids (Simoneit, 1977) were only detected in trace quantities in 416A-28-4. Complex mixtures of polar and hydroxylated fatty acids were observed in all three sections; these fractions, however, were not studied in detail.
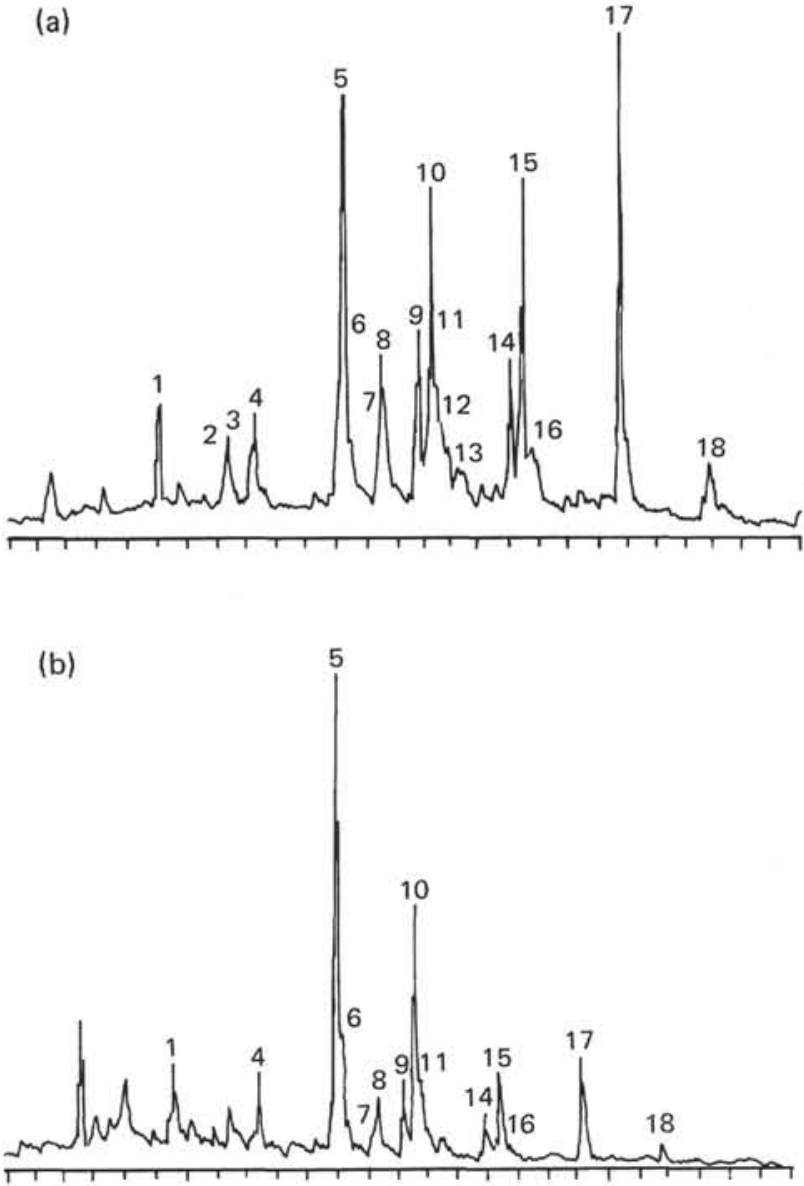

Figure 4. Partial mass fragmentograms of m/e 191 for the aliphatic hydrocarbon fractions from Sections $416 A-1-3(a, \times 10.1)$ and $28-4(b, \times 14.9)$. Peak numbers refer to Table 6.

TABLE 6

Triterpenoid Hydrocarbons, Hole 416A

\begin{tabular}{|c|c|c|c|c|c|c|c|}
\hline \multirow[b]{2}{*}{ Peak $^{a}$} & \multirow[b]{2}{*}{ Assignment $t^{b}$} & \multirow[b]{2}{*}{ Formula } & \multirow{2}{*}{$\begin{array}{c}\text { Structure } \\
\text { R }\end{array}$} & \multirow[b]{2}{*}{ Mol. Wt. } & \multicolumn{3}{|c|}{$\begin{array}{c}\text { Concentration in } \\
\text { Core Sections } \\
\text { (ng/g) }\end{array}$} \\
\hline & & & & & $14-4$ & $18-3$ & 28.4 \\
\hline 1 & $\begin{array}{l}\text { 22,29,30-Trisnomeohop- } \\
\text { 13(18)-ene }\end{array}$ & $\mathrm{C}_{27} \mathrm{H}_{44}$ & IV,H & 368 & 5.0 & 1.2 & 4.0 \\
\hline 2 & $\begin{array}{l}22,29,30 \text {-Trisnothop- } \\
\text { 17(21)-ene }\end{array}$ & $\mathrm{C}_{27}{ }^{\mathrm{H}_{44}}$ & $\mathrm{~V}, \mathrm{H}$ & 368 & & & \\
\hline 3 & $\begin{array}{l}\text { 17aH-22,29,30- } \\
\text { Trisnorhopane }\end{array}$ & $\mathrm{C}_{27} \mathrm{H}_{46}$ & VI,H & 370 & 3.5 & 0.9 & \\
\hline 4 & $22,29,30$-Trisnorhopane & $\mathrm{C}_{27} \mathrm{H}_{46}$ & VII,H & 370 & 7.8 & 1.7 & 5.5 \\
\hline 5 & 30-Norneohop-13(18)-ene & $\mathrm{C}_{29} \mathrm{H}_{48}$ & IV, $\mathrm{C}_{2} \mathrm{H}_{5}$ & 396 & & & \\
\hline 6 & 30-Norhop-17(21)-ene & $\mathrm{C}_{29} \mathrm{H}_{48}$ & $\mathrm{~V}, \mathrm{C}_{2} \mathrm{H}_{5}$ & 396 & 18. & 5.8 & \\
\hline 7 & Hop-17(21)-ene & $\mathrm{C}_{30} \mathrm{H}_{50}$ & $\mathrm{~V}, \mathrm{CH}\left(\mathrm{CH}_{3}\right)_{2}$ & 410 & & & \\
\hline 8 & 30-Normoretane & $\mathrm{C}_{29} \mathrm{H}_{50}$ & VIII, $\mathrm{C}_{2} \mathrm{H}_{5}$ & 398 & 15.2 & 3.7 & \\
\hline 9 & 17aH-Hopane & $\mathrm{C}_{30} \mathrm{H}_{52}$ & $\mathrm{~V} 1, \mathrm{CH}\left(\mathrm{CH}_{3}\right)_{2}$ & 412 & 5.5 & 1.9 & $\cdot 3.5$ \\
\hline 10 & Neohop-13(18)-ene & $\mathrm{C}_{30} \mathrm{H}_{50}$ & IV, $\mathrm{CH}\left(\mathrm{CH}_{3}\right)_{2}$ & 410 & 16.1 & 54 & 15 \\
\hline 11 & 30-Norhopane & $\mathrm{C}_{29} \mathrm{H}_{50}$ & VII, $\mathrm{C}_{2} \mathrm{H}_{5}$ & 398 & & & \\
\hline 12 & Homohop-17(21)-ene & $\mathrm{C}_{31} \mathrm{H}_{52}$ & $\mathrm{~V}, \mathrm{CH}\left(\mathrm{CH}_{3}\right) \mathrm{C}_{2} \mathrm{H}_{5}$ & 424 & 8.9 & 2.1 & 1.8 \\
\hline 13 & Homohop-17(21)-ene & $\mathrm{C}_{31} \mathrm{H}_{52}$ & $\mathrm{v}, \mathrm{CH}\left(\mathrm{CH}_{3}\right) \mathrm{C}_{2} \mathrm{H}_{5}$ & 424 & 3.1 & 1.2 & 1.0 \\
\hline 14 & 17aH-horhohopane & $\mathrm{C}_{31} \mathrm{H}_{54}$ & vi, $\mathrm{CH}\left(\mathrm{CH}_{3}\right) \mathrm{C}_{2} \mathrm{H}_{5}$ & 426 & 4.2 & 1.8 & 2.5 \\
\hline 15 & Hopane & $\mathrm{C}_{30} \mathrm{H}_{52}$ & $\mathrm{VII}, \mathrm{CH}\left(\mathrm{CH}_{3}\right)_{2}$ & 412 & 9.3 & 3.9 & 5.1 \\
\hline 16 & Homomoretane & $\mathrm{C}_{31} \mathrm{H}_{54}$ & VIII, $\mathrm{CH}\left(\mathrm{CH}_{3}\right) \mathrm{C}_{2} \mathrm{H}_{5}$ & 426 & 3.5 & 0.8 & 0.9 \\
\hline 17 & Homohopane & $\mathrm{C}_{31} \mathrm{H}_{54}$ & $\mathrm{VII}, \mathrm{CH}\left(\mathrm{CH}_{3}\right) \mathrm{C}_{2} \mathrm{H}_{5}$ & 426 & 27.3 & 11.7 & 10.0 \\
\hline 18 & Bishomohopane & $\mathrm{C}_{32} \mathrm{H}_{56}$ & $\mathrm{VII}, \mathrm{CH}\left(\mathrm{CH}_{3}\right) \mathrm{C}_{3} \mathrm{H}_{7}$ & 440 & 5.9 & 1.7 & 1.6 \\
\hline
\end{tabular}

Note: Structures are shown in Appendix, this chapter.

Peak designations of Figure 4

Assignments on basis of individual mass spectral characteristics and capillary GLC retention data of standards, or by comparison with triterpenoid identification in Leg 48 samples (Barnes et al. in press).

${ }^{c}$ Dry wt, sediment, quantitation from mass fragmentography of $\mathrm{m} / \mathrm{e} 191$, taking into account the intensity of this ion as given in Leg 48 report (Barnes et al., in press). 


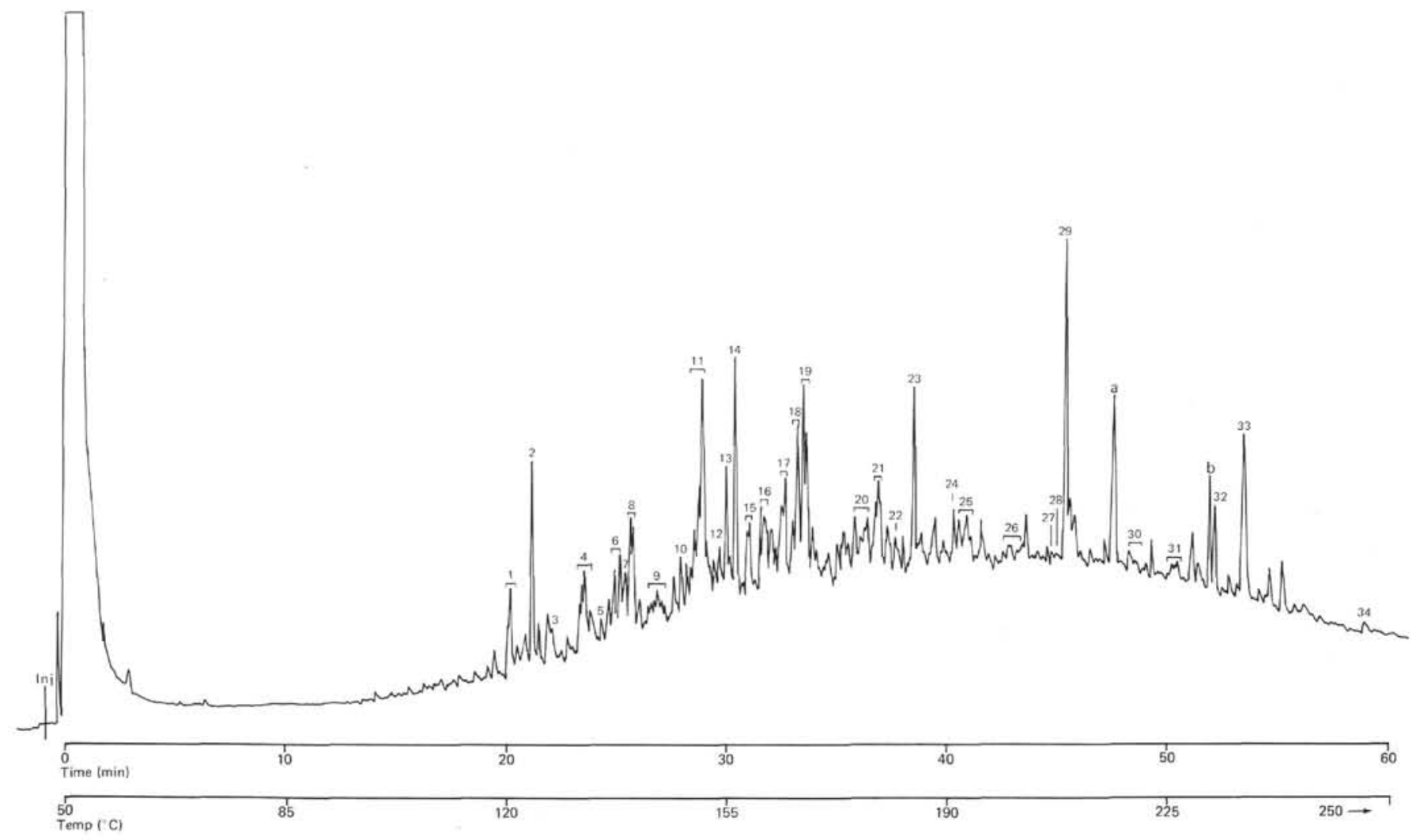

Figure 5. Gas chromatogram of the polynuclear-aromatic-hydrocarbon (PAH) fraction from Section 416A-18-3. Peak numbers refer to Table 7, except for peaks $a$ and $b$, which are contaminants ( $a$ phthalate and an unknown component) found in the blank analyses. An unresolved complex mixture of PAH is also present. Conditions: $20 \mathrm{~m}$ $\mathrm{OV}-1 \mathrm{WCOT}$ glass capillary column, programmed from 50 to $250^{\circ} \mathrm{C}$ at $3.5^{\circ} \mathrm{C} / \mathrm{min}, \mathrm{N}_{2}$ carrier gas.

\section{DISCUSSION}

\section{Straight- and Branched-Chain Components}

Long-chain $n$-alkanes predominate in each of the three hydrocarbon distributions (Figure 1). The strong predominance of odd chain lengths in addition to a common maximum at $n-\mathrm{C}_{27}$ is consistent with a higher plant origin for these alkanes (Barnes et al., in press). The abundances of these alkanes in the top and bottom core sections are remarkably similar (Table 2 ), suggesting a similar level of higher plant contribution to these sections.

In contrast to these high $n$-alkane concentrations, monocarboxylic acids are comparatively minor constituents of the solvent-extractable lipids. The major proportion of fatty acids in these sediments is probably present in non-solvent-extractable forms, although we do not have data on this point at present. In view of this, a degree of caution must be exercised in the interpretation of environments from the fatty acid distributions.

Long-chain fatty acids, considered to derive from higher plants, do not predominate in any of the core sections, owing to a contribution of short-chain fatty acids from autochthonous sources. These short-chain acids are most abundant in the middle core, 416A-18-3, which can only be caused by an increased autochthonous contribution at this level. The presence of 16:1, 18:1, and 18:2 together with a low abundance of odd-chain and branched acids suggests a predominantly algal origin for these short-chain $\left(<\mathrm{C}_{20}\right)$ acids. This correlates well with the greater amounts of amorphous algal debris noted in the kerogen description of this core section (G. C. Speers and T. Doran, personal communication).

The low abundance of iso- and anteiso-branched acids in all three samples suggests a minimal contribution to the sedimentary organic matter from gram-positive bacteria. This, taken together with the absence of branched mono-unsaturated acids, even in Core 416A18-3, where straight-chain mono-unsaturated fatty acids were found, further suggests that the sulfate-reducing bacterium, Desulfovibrio desulfuricans, has not been an important contributor to the sedimentary lipids (Boon et al., 1977).

Algal and, to a lesser extent, bacterial sources probably account for the small quantities of short-chain $n$-alkanes present. Note that the $n$-alkane distributions appear to be less sensitive indicators of autochthonous contribution than the fatty acid profiles. This is presumably because algae and bacteria have fewer $n$-alkanes than do the higher plants. 
TABLE 7

Aromatic Hydrocarbon Assignments, Mass Spectral Characteristics, and Quantitations, Hole 416A

\begin{tabular}{|c|c|c|c|c|c|c|c|c|c|}
\hline \multirow[b]{2}{*}{ Peak $^{\mathrm{a}}$} & \multirow[b]{2}{*}{ Compound(s) } & \multirow[b]{2}{*}{ Formula } & \multirow{2}{*}{$\begin{array}{l}\text { Structure } \\
\quad \mathrm{R}\end{array}$} & \multirow{2}{*}{$\begin{array}{l}\text { Number } \\
\text { of } \\
\text { 1somers }\end{array}$} & \multicolumn{2}{|r|}{$\begin{array}{l}\text { Diagnostic Ions }{ }^{\mathrm{i}} \\
\text { (intensities) }\end{array}$} & \multicolumn{3}{|c|}{$\begin{array}{l}\text { Concentration in } \\
\text { ( ore Sections }{ }^{\mathrm{k}} \\
\text { (ng/g) }\end{array}$} \\
\hline & & & & & $\mathrm{M}^{+}$ & Fragment lons & $14-4$ & $18-3$ & $28-4$ \\
\hline 1 & Methylfluorenes ${ }^{b}$ & $\mathrm{C}_{14} \mathrm{H}_{12}$ & $\mathrm{IX}, \mathrm{CH}_{3}$ & 3 & $180(90)^{j}$ & $165(100)$ & 0.4 & 1.1 & $\operatorname{Tr}$ \\
\hline 2 & Unknown & $\mathrm{C}_{14} \mathrm{H}_{16}$ & - & - & $184(100)$ & $169(82)$ & $\operatorname{Tr}$ & 3.0 & $\operatorname{Tr}$ \\
\hline 3 & Phenanthrene ${ }^{c}$ & $\mathrm{C}_{14} \mathrm{H}_{10}$ & $\mathrm{X}$ & - & $178(100)$ & & 1.2 & 0.4 & 0.3 \\
\hline 4 & Ethylfluorenes ${ }^{b, d}$ & $\mathrm{C}_{15} \mathrm{H}_{14}$ & $\mathrm{IX}, \mathrm{C}_{2} \mathrm{H}_{5}$ & 4 & $194(90)^{j}$ & $179(100) 178(53)$ & 0.8 & 2.1 & 0.7 \\
\hline 5 & Unknown & $\mathrm{C}_{16} \mathrm{H}_{16}$ & - & 2 & $208(30)^{\mathrm{j}}$ & $\begin{array}{l}194(90)^{j} 193(38)^{j} \\
179(100) 178(60)^{j}\end{array}$ & 0.2 & 0.4 & 0.3 \\
\hline 6 & Methylphenanthrenes ${ }^{\mathrm{b}, \mathrm{e}}$ & $\mathrm{C}_{15} \mathrm{H}_{12}$ & $\mathrm{XI}, \mathrm{CH}_{3}$ & 2 & $192(100)$ & $191(54)^{j}$ & 0.3 & 2.0 & 0.3 \\
\hline 7 & $4 \mathrm{H}$-cyclopenta $(\mathrm{d}, \mathrm{e}, \mathrm{f})$ phenanthrene $\mathrm{e}^{\mathrm{b}}$ & $\mathrm{C}_{15} \mathrm{H}_{10}$ & XII & - & $190(100)$ & $189(98)$ & 0.2 & 0.5 & 0.1 \\
\hline 8 & Methylphenanthrenes $\mathrm{b}, \mathrm{e}$ & $\mathrm{C}_{15} \mathrm{H}_{12}$ & $\mathrm{XI}, \mathrm{CH}_{3}$ & 3 & $192(100)$ & $191(51)^{\mathrm{j}}$ & 0.7 & 2.2 & 0.6 \\
\hline 9 & Unknown & $\mathrm{C}_{16} \mathrm{H}_{16}$ & - & 5 & $\begin{array}{l}208(60) \\
208(60) \\
208(100)\end{array}$ & $\begin{array}{l}193(50) 179(100) \\
193(100) 179(30) \\
207(90)\end{array}$ & 0.4 & 1.1 & 0.7 \\
\hline 10 & Dimethylphenanthrenes ${ }^{\mathrm{b}, \mathrm{e}}$ & $\mathrm{C}_{16} \mathrm{H}_{14}$ & $\mathrm{XI},\left(\mathrm{CH}_{3}\right)_{2}$ & 2 & $206(50)$ & $191(100)$ & 0.3 & 0.7 & 0.2 \\
\hline 11 & Ethylphenanthrenes ${ }^{\mathrm{d}, \mathrm{e}}$ & $\mathrm{C}_{16} \mathrm{H}_{14}$ & $\mathrm{XI}, \mathrm{C}_{2} \mathrm{H}_{5}$ & 5 & $206(100)$ & $205(51)^{\mathrm{j}} 191(55)^{\mathrm{j}}$ & 3.5 & 4.8 & 3.0 \\
\hline 12 & Fluoranthene ${ }^{\mathrm{c}}$ & $\mathrm{C}_{16} \mathrm{H}_{10}$ & $\mathrm{XIII}$ & - & $202(100)$ & & 0.1 & 0.2 & 0.1 \\
\hline 13 & Pyrene ${ }^{c}$ & $\mathrm{C}_{16} \mathrm{H}_{10}$ & XIV & - & $202(100)$ & & 0.6 & 1.8 & 1.1 \\
\hline 14 & Dihydro(4,5)pyrene $\mathrm{e}^{\mathrm{e}}$ & $\mathrm{C}_{16} \mathrm{H}_{12}$ & $\mathrm{XV}$ & - & $204(100)$ & $203(95) 202(70)$ & 2.3 & 3.6 & 2.3 \\
\hline 15 & Ethyl-4H-cyclopenta(d,e,f)phenanthrenes ${ }^{\mathrm{d}, e}$ & $\mathrm{C}_{17} \mathrm{H}_{14}$ & $\mathrm{XVI}, \mathrm{C}_{2} \mathrm{H}_{5}$ & 2 & $218(85)^{j}$ & $203(100) 202(74)$ & 1.7 & 1.5 & 1.0 \\
\hline 16 & Propylphenanthrenes $\mathrm{e}, \mathrm{f}$ & $\mathrm{C}_{17} \mathrm{H}_{16}$ & $\mathrm{XI}, \mathrm{C}_{3} \mathrm{H}_{7}$ & 3 & $220(100)$ & $205(55)^{j}$ & 1.0 & 1.9 & 0.8 \\
\hline 17 & Methylfluoranthenes $\mathrm{e} /$ benzanthrene $\mathrm{e}^{\mathrm{e}}$ & $\mathrm{C}_{17} \mathrm{H}_{12}$ & $\mathrm{XVII}, \mathrm{CH}_{3} / \mathrm{XVIII}$ & 2 & $216(100)$ & $215(97)^{\mathrm{j}}$ & 0.5 & 1.8 & 0.4 \\
\hline 18 & Methyldihydro $(4,5)$ pyrenes $^{\mathrm{e}}$ & $\mathrm{C}_{17} \mathrm{H}_{14}$ & $\mathrm{XIX}, \mathrm{CH}_{3}$ & 3 & $218(100)$ & $217(40)^{\mathrm{j}}$ & 2.5 & 2.8 & 2.2 \\
\hline 19 & Methylpyrenes $^{\mathrm{e}}$ & $\mathrm{C}_{17} \mathrm{H}_{12}$ & $\mathrm{XX}, \mathrm{CH}_{3}$ & 2 & $216(100)^{\mathrm{j}}$ & $215(97)^{j}$ & 1.7 & 3.9 & 2.1 \\
\hline 20 & Propyl-4H-cyclopenta(d,e,f)phenanthrenes $\mathrm{e}, \mathrm{f}$ & $\mathrm{C}_{18} \mathrm{H}_{16}$ & $\mathrm{XVI}, \mathrm{C}_{3} \mathrm{H}_{7}$ & 5 & $232(100)$ & $231(47)^{\mathrm{j}}$ & 0.8 & 1.6 & 0.6 \\
\hline 21 & Ethylpyrenes $\mathrm{d}, \mathrm{e}$ & $\mathrm{C}_{18} \mathrm{H}_{14}$ & $\mathrm{XX}, \mathrm{C}_{2} \mathrm{H}_{5}$ & 4 & $230(100)$ & $215(45)^{\mathrm{j}}$ & 2.2 & 2.0 & 2.0 \\
\hline 22 & Chrysene ${ }^{c}$ & $\mathrm{C}_{18} \mathrm{H}_{12}$ & $\mathrm{XXI}^{2}$ & - & $228(100)$ & & 0.6 & 0.4 & 0.3 \\
\hline 23 & Unknown & $\mathrm{C}_{24} \mathrm{H}_{38}$ ? & - & 1 & $326(96)$ & $311(100)$ & $\operatorname{Tr}$ & 2.6 & $\operatorname{Tr}$ \\
\hline 24 & Unknown & $\mathrm{C}_{20} \mathrm{H}_{20}$ & - & 3 & $260(100)$ & $245(90)^{\mathfrak{j}}$ & 0.7 & 0.8 & $\operatorname{Tr}$ \\
\hline 25 & Methylchrysenes b,e & $\mathrm{C}_{19} \mathrm{H}_{14}$ & $\mathrm{XXII}, \mathrm{CH}_{3}$ & 3 & $242(100)$ & $241(35)^{\mathrm{j}}$ & 1.0 & 1.3 & $\operatorname{Tr}$ \\
\hline 26 & Ethylchrysenes ${ }^{\mathrm{d}, \mathrm{e}}$ & $\mathrm{C}_{20} \mathrm{H}_{16}$ & $\mathrm{XXII}, \mathrm{C}_{2} \mathrm{H}_{5}$ & 4 & $256(100)$ & $241(10)^{\mathrm{j}}$ & 1.0 & 0.5 & $\operatorname{Tr}$ \\
\hline 27 & Benzofluoranthenes $b$ & $\mathrm{C}_{20} \mathrm{H}_{12}$ & $\mathrm{XXII} \mathrm{g}^{2}$ & 2 & $252(100)$ & & 0.4 & 0.1 & 0.4 \\
\hline 28 & Benzopyrenes ${ }^{b}$ & $\mathrm{C}_{20} \mathrm{H}_{12}$ & XXIV,XXV & 2 & $252(100)$ & & 0.7 & $\mathrm{Tr}$ & 0.5 \\
\hline 29 & Perylene ${ }^{c}$ & $\mathrm{C}_{20} \mathrm{H}_{12}$ & XXVI & - & $252(100)$ & & 3.7 & 5.0 & 2.6 \\
\hline 30 & Methylperylenes ${ }^{\mathrm{e}}$ & $\mathrm{C}_{21} \mathrm{H}_{14}$ & $\mathrm{XXVII}, \mathrm{CH}_{3}$ & 2 & $266(100)$ & $265(55) 252(26)$ & 0.6 & 0.4 & 0.8 \\
\hline 31 & Ethylperylenes ${ }^{\mathrm{d}, \mathrm{e}}$ & $\mathrm{C}_{22} \mathrm{H}_{16}$ & XXVII, $\mathrm{C}_{2} \mathrm{H}_{5}$ & 3 & $280(100)$ & & $\mathrm{Tr}$ & 0.3 & 0.2 \\
\hline \multirow[t]{2}{*}{32} & Benzo $(g, h, i)$ perylene ${ }^{b}$ & $\mathrm{C}_{22} \mathrm{H}_{12}$ & XXVIII & - & $276(100)$ & & 0.3 & 0.2 & $\operatorname{Tr}$ \\
\hline & $\begin{array}{l}\text { (3'-Ethylcyclopenteno-7,8)-1,1-dimethyl- } \\
\text { tetrahydro(1,2,3,4)chrysene }\end{array}$ & $\mathrm{C}_{25} \mathrm{H}_{28}$ & XXIX & - & $328(62)$ & $313(65) 299(100) 257(24)$ & 0.3 & 1.1 & 0.2 \\
\hline \multirow{2}{*}{$\begin{array}{l}33 \\
34\end{array}$} & 7-Methyl-3'-ethyl-1,2-cyclopentenochrysene ${ }^{\text {b }}$ & $\mathrm{C}_{24} \mathrm{H}_{22}$ & $\mathrm{XXX}$ & - & $310(45)$ & $281(100) 266(25) 265(26)$ & 3.0 & 2.8 & 0.6 \\
\hline & $\begin{array}{l}\text { ?, 7-Dimethyl-3'-ethyl-1,2-cyclopenteno- } \\
\text { chryseneb }\end{array}$ & $\mathrm{C}_{25} \mathrm{H}_{24}$ & $\mathrm{XXXI}, \mathrm{CH}_{3}$ & 1 & $324(52)$ & $295(100) 280(14) 279(13)$ & 0.8 & 0.2 & $\operatorname{Tr}$ \\
\hline
\end{tabular}

Note: $\mathrm{Tr}=$ trace quantity $(<0.1 \mathrm{ng} / \mathrm{g}$ dry wt. sediment $)$. Structures are shown in Appendix, this chapter.

apeak designations of Figure 5 .

${ }^{b}$ Assignments on basis of comparison with reference mass spectra and capillary GLC retention data.

${ }^{c}$ Assignments made from mass spectra and capillary GLC co-injection.

${ }^{\mathrm{d}}$ May be dimethyl.

${ }^{\mathrm{e}}$ Assignments made by mass spectral interpretation and capillary GLC retention data.

f May be trimethyl or methylethyl.

$\mathrm{g}$ Other structural isomers present.

${ }^{h}$ Number of isomers determined from capillary GLC or mass fragmentography.

${ }^{\mathrm{i}}$ Mass spectra recorded at $40 \mathrm{eV}$.

${ }$ Average ion intenstiy of the isomers.

${ }^{\mathrm{k}}$ Dry wt, sediment, quantitated by GLC or mass fragmentography.

\section{Steroidal Components}

The diversity of rearranged sterenes observed in the three samples cannot be explained by the known rearrangement of sterols via sterene intermediates under clay-rich conditions (Rubinstein et al., 1975; Dastillung and Albrecht, 1977). This conversion generates 20R and
$20 \mathrm{~S}$ rearranged sterene diastereoisomers for each carbon number (typically $\mathrm{C}_{27}, \mathrm{C}_{28}, \mathrm{C}_{29}$ Rubinstein et al., 1975) whereas six $\mathrm{C}_{28}$ components have been recognized herein, for example, in Section 416A-18-3 (Table 3). An additional diagenetic process therefore appears to be occurring to generate additional rearranged sterene isomers. 
TABLE 8

Metalloporphyrins: UV-Visible Data (in $\mathrm{CH}_{2} \mathrm{Cl}_{2}$ ) and Concentrations, Hole 416A

\begin{tabular}{|c|c|c|c|c|c|c|}
\hline \multirow[b]{2}{*}{ Section } & \multicolumn{4}{|c|}{ Bands $(n m \pm 1)$} & \multirow[b]{2}{*}{ Species } & \multirow{2}{*}{$\begin{array}{c}\text { Concentration } \\
(\mu \mathrm{b} / \mathrm{g} \text { dry } \\
\text { wt. sediment })\end{array}$} \\
\hline & Soret & $\alpha$ & $\beta$ & $\alpha / \beta^{\mathrm{a}}$ & & \\
\hline $14-4$ & 392 & 514 & 550 & 2.4 & Nickel & 0.08 \\
\hline $18-3$ & 392 & 514 & 550 & 2.3 & Nickel & 0.10 \\
\hline $28-4$ & 392 & 514 & 550 & 2.3 & Nickel & 0.05 \\
\hline
\end{tabular}

${ }^{\mathrm{a}}$ Ratio of absorbances of $\alpha$ and $\beta$ bands.

${ }^{b}$ Estimated using the molar extinction coefficient: 34,820 at 550 nm (Baker et al., 1978).
The carbon number range of the steroidal compounds (see also below) is atypical of higher plants (where $\mathrm{C}_{28}$ and $\mathrm{C}_{29}$ components dominate; e.g., Huang and Meinschein, 1976) indicating that they are unlikely to be the dominant contributor of sterols to the sediment. In addition, the rearranged sterenes include a $\mathrm{C}_{30}$ component, probably derived from a $\mathrm{C}_{30}$ 4-desmethyl sterol. The rarity of $\mathrm{C}_{30}$ sterols in terrestrial organisms relative to their known presence in marine organisms suggests that this $\mathrm{C}_{30}$ sterene is characteristic of a marine source. The 4-methyl rearranged sterenes parallel the rearranged sterenes in the variety of their isomers for each carbon number, and therefore the

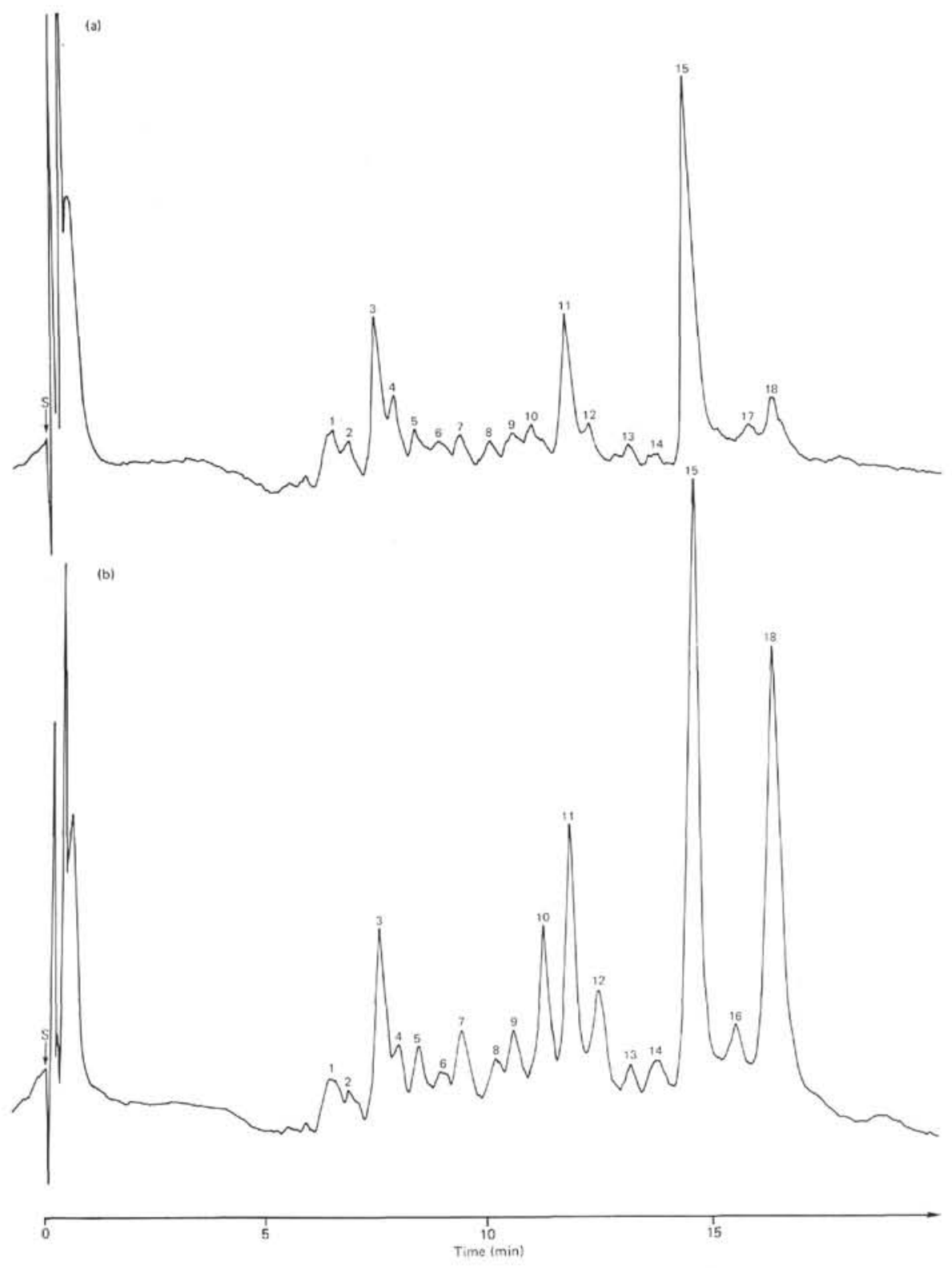

Figure 6. HPLC traces of demetallated petroporphyrins of core sections: (a) 416A-14-4, (b) 416A-18-3. Peak numbers refer to Table 9. For conditions, see Experimental Procedures. 
TABLE 9

Relative Concentrations of Demetallated Porphyrins, Hole 416A

\begin{tabular}{|c|c|c|c|c|}
\hline \multirow[b]{2}{*}{$\begin{array}{c}\text { Peak } \\
\text { (Figure 6) }\end{array}$} & \multirow[b]{2}{*}{$\begin{array}{l}\text { Rel. Ret. Time } \\
(\min )\end{array}$} & \multirow[b]{2}{*}{$\begin{array}{c}\text { Tentative Assignment } \\
\text { ( } C_{\text {no }} \text { and Substituent Type) }\end{array}$} & \multicolumn{2}{|c|}{ Section } \\
\hline & & & $\begin{array}{l}14 \cdot 4 \\
(\%)^{b}\end{array}$ & $\begin{array}{l}18-3 \\
(\%)^{\mathrm{b}}\end{array}$ \\
\hline 1 & 6.3 & Unknown & 5.4 & 1.8 \\
\hline 2 & 6.7 & Unknown & 2.7 & 1.6 \\
\hline 3 & 7.3 & Unknown & 11.4 & 13.8 \\
\hline 4 & 7.7 & Unknown & 3.0 & 1.1 \\
\hline 5 & 8.2 & $\mathrm{C}_{30} \mathrm{E}^{\mathrm{d}}$ & 1.7 & 1.1 \\
\hline 6 & 8.7 & $\mathrm{C}_{32} \mathrm{E}(4 \mathrm{Me}, 4 \mathrm{Et})^{\mathrm{C}}$ & 1.1 & 0.2 \\
\hline 7 & 9.2 & $\mathrm{C}_{29} \mathrm{E}(5 \mathrm{Me}, 2 \mathrm{Et}, \mathrm{H})^{\mathrm{d}}$ & 1.4 & 1.3 \\
\hline 8 & 9.8 & $\mathrm{C}_{31} \mathrm{E}(5 \mathrm{Me}, 3 \mathrm{Et})^{\mathrm{c}}$ & 0.7 & 0.2 \\
\hline 9 & 10.3 & $\mathrm{C}_{28} \mathrm{E}^{\mathrm{d}}$ & 1.4 & 0.8 \\
\hline 10 & 10.7 & $\mathrm{C}_{30} \mathrm{E}(6 \mathrm{Me}, 2 \mathrm{Et})^{\mathrm{C}}$ & 2.9 & 7.0 \\
\hline 11 & 11.5 & $\mathrm{C}_{30} \mathrm{D}^{\mathrm{d}}$ & 11.7 & 10.3 \\
\hline 12 & 12.1 & Unknown & 1.7 & 3.8 \\
\hline 13 & 12.9 & $\mathrm{C}_{31} \mathrm{D}+$ other components ${ }^{\mathrm{d}}$ & 0.5 & 0.5 \\
\hline 14 & 13.5 & $\mathrm{C}_{33} \mathrm{D}^{\mathrm{d}}$ & 0.6 & 0.5 \\
\hline 15 & 14.3 & $\mathrm{C}_{32} \mathrm{D}^{\mathrm{d}}$ & 44.1 & 31.2 \\
\hline 16 & 15.2 & $\mathrm{C}_{32} \mathrm{D}^{\mathrm{d}}$ & n.d. & 0.7 \\
\hline 17 & 15.6 & Unknown & 2.8 & n.d. \\
\hline 18 & 16.0 & $\mathrm{C}_{31} \mathrm{D}^{\mathrm{c}}$ & 7.0 & 23.8 \\
\hline
\end{tabular}

Note: $n . d .=$ not detected $: \mathrm{Me}=$ methyl; $\mathrm{Et}=$ ethyl $\mathrm{E}=\mathrm{Etio}$ porphyrin, XXXIII (demetallated); D = DPEP porphyrin, XXXIV (demetallated).

${ }^{\text {a }}$ Relative to solvent front (S) in Figure 6 (accuracy $\pm 0.3 \mathrm{~min}$ ).

$\mathrm{b}_{\text {Percent }}$ of total by triangulation and peak-area measurement.

${ }^{\mathrm{C}} \mathrm{Co}$-injected with component isolated from an Eocene bitumen (analyzed by NMR; Quirke et al., unpublished results) or with etioporphyrin-I $\left(\mathrm{C}_{32} \mathrm{E}\right)$.

$\mathrm{d}_{\mathrm{By}}$ comparison of relative retention time with components isolated from an Eocene bitumen (Quirke et al., unpublished results).

TABLE 10

Total Monocarboxylic Acids, Hole 416A

\begin{tabular}{ccc}
\multicolumn{3}{c}{ Acids, Hole 416A } \\
\hline & $\begin{array}{c}\text { Concentrations of } \\
\text { Chain-Length Ranges } \\
\text { (ng/g) }\end{array}$ \\
Section & $\mathrm{C}_{10}{ }^{\mathrm{C}} \mathrm{C}_{20}$ & $\mathrm{C}_{21}-\mathrm{C}_{32}$ \\
\hline $14-4$ & 9 & 6 \\
$18-3$ & 18.3 & 0.3 \\
$28-4$ & 0.9 & 0.2 \\
\hline
\end{tabular}

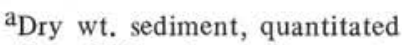
from GLC and mass fragmentography of $\mathrm{m} / \mathrm{e} 74$.

4-methyl group evidently does not greatly affect the rearrangement process.

The absence of rearranged steranes (shown by $\mathrm{m} / \mathrm{e}$ 259 and $\mathrm{m} / \mathrm{e} 273$ mass fragmentograms) at detectable leveis, while a series of steranes (m/e 217) is present in all three samples, indicates that the sterene to sterane conversion occurs under less severe diagenetic or maturation conditions than the rearranged sterene to rearranged sterane reduction. This can be attributed to the steric hindrance of the double bond in rearranged sterenes. The samples, therefore, appear to be less mature than the shallow Toarcian shales of the Paris Basin found at Jouy (Rubinstein et al., 1975; Ensminger, 1977), and more closely resemble the diagenetic stage of the Messel shale (Ensminger et al., 1978).
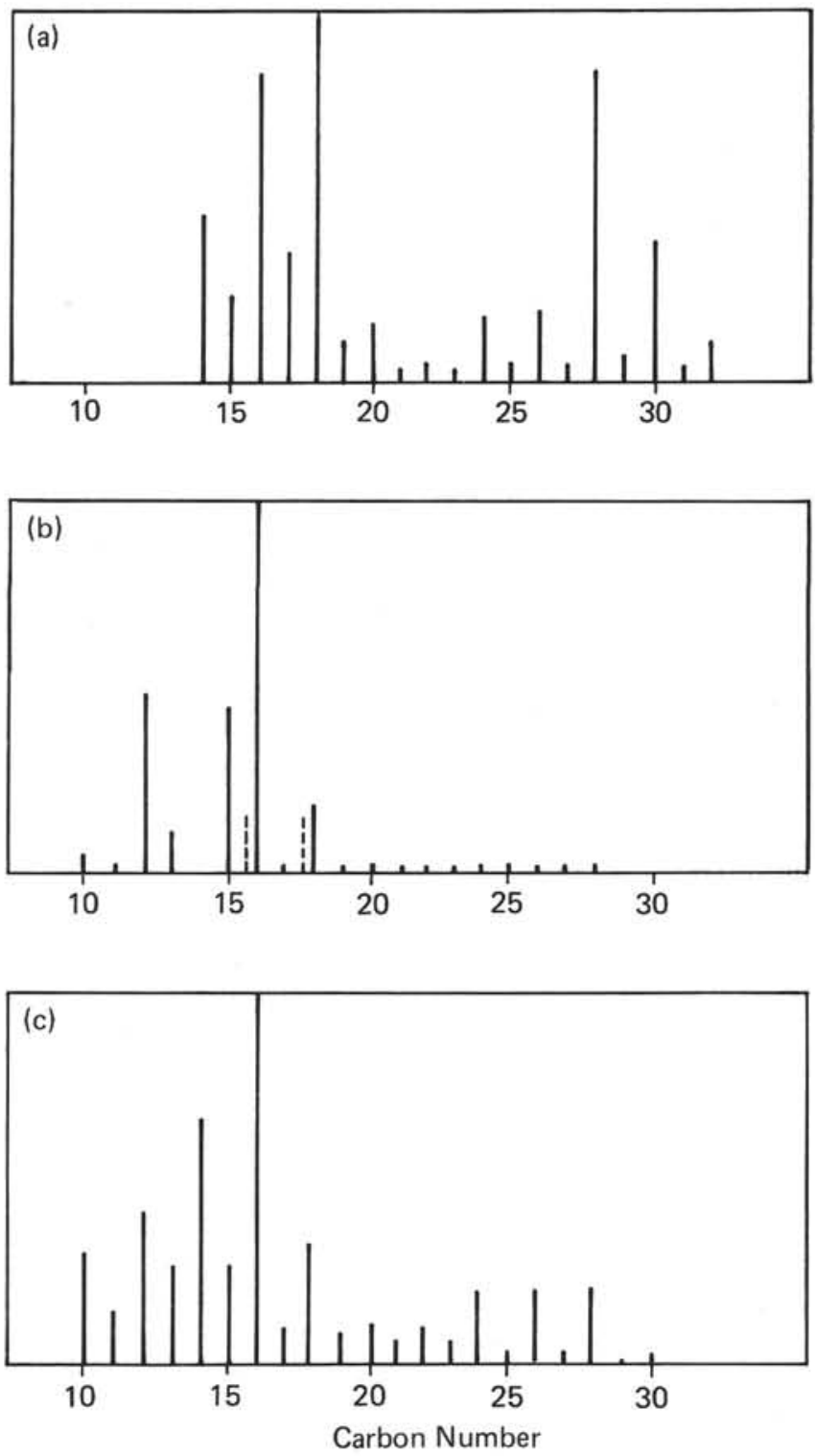

Figure 7. Relative concentrations of $\mathrm{n}$-alkanoic acids as methyl esters (FAME) (unbroken lines), 16:1 and 18:1 (broken lines) in Sections: (a) 416A-14-4, (b) $416 A-18-3$, (c) 416A-28-4. Acids are designated as: number of carbon atoms: number of double bonds.

The presence of sterenes $(\mathrm{m} / \mathrm{e} 215)$ in significant quantities in one of the samples suggests that their conversion to steranes and (or) rearranged sterenes is not complete. The sterenes found could, however, be derived from the clay-catalyzed dehydration of saturated sterols effected by the freeze-drying process, as shown in a recent study of the technique (Van de Meent et al., 1977).

The mono-aromatic steroidal compounds ( $\mathrm{m} / \mathrm{e} 253$ ) appear (like the series of rearranged sterenes, sterenes, and steranes) to be derived from diagenetic aromatiza- 
tion of the original contribution of sterols and stanols. The absence of reported occurrences of these aromatic steroids in Holocene sediments supports the belief that they form by chemical aromatization. Unfortunately, the observed lability of the rearranged sterenes invalidates quantitative comparisons between them and the aromatic steroidal components; it is difficult, therefore, to evaluate the possibility that the aromatic steroids are derived from the rearranged sterenes ( $\mathrm{P}$. Albrecht, personal communication).

\section{Triterpenoidal Components}

Sections $416 \mathrm{~A}-14-4$ and $416 \mathrm{~A}-18-3$ possess virtually identical distributions of triterpenes and triterpanes, whereas Section 416A-28-4 (Figure 4) shows greater proportions of 30-norneohop-13(18)-ene and neohop-13 (18)-ene. This difference, suggesting enhanced isomerization, can perhaps be attributed to the greater maturity of the lowest sample. The absence of neohopanes indicates that saturation of the 13(18) double bond does not occur at the maturity level of these samples.

The high relative abundance of the $17 \beta \mathrm{H}$ hopane isomers relative to their $17 \alpha \mathrm{H}$ counterparts and the absence of $22 \mathrm{R}$ and $\mathrm{S}$ diastereoisomers is further evidence of the immaturity of these samples comparable to the Messel shale (e.g., Wardroper et al., 1977) rather than oils and oil-source rocks (Dastillung and Albrecht, 1976; Van Dorsselaer et al., 1974).

The aromatized triterpenoid hydrocarbons (peaks 32-34, Table 7) recognized in all three samples are thought to be derived from aliphatic hopanoid precursors, suggesting the process of progressive chemical aromatization (Spyckerelle, 1975; Greiner et al., 1976). The ratios of the pentacyclic hopanoid-derived phenanthrenes to the chrysenes for the three samples do not vary sufficiently to suggest an increasing maturity, on this basis, with depth.

The hopanoid chrysene (peak 33, Figure 5; Table 7) has been found in Holocene surface sediments from the Norwegian Sea, about $150 \mathrm{~km}$ north of Trondheim, suggesting that aromatization can be an early-stage diagenetic process, probably resulting from bacterial activity or contribution (Tissier and Spyckerelle, 1977).

\section{Polynuclear Aromatic Hydrocarbons (PAH)}

In an ancient sediment, the constituent polynuclear aromatic hydrocarbons (PAH) may have been generated at three different stages: (1) Predepositional; contributions from either (a) weathering of oil shales, coals, and other preconsolidated or thermally mature sources, or (b) natural combustion of organic matter, such as the products of grassland and forest fires (Blumer and Youngblood, 1975), followed by aqueous or eolian transportation to the site of deposition. (2) Syndepositional; in-situ generation of aromatic hydrocarbons from functionalized precursors, e.g., the proposed transformation of extended quinone pigments to perylene (Orr and Grady, 1967; Aizenshtat, 1973; Laflamme and Hites, 1978). (3) Postdepositional; formation of aromatic components by diagenetic aromatization, aided by active clay surfaces, e.g., production of various aromatized terpenes (Brooks, 1948; Mair, 1964; Blumer, 1965; Spyckerelle, 1975; Frenkel and Heller-Kallai, 1978).

The airborne pollutants derived from the combustion of fossil fuels, namely coal, wood, and petroleum (Lee et al., 1976, 1977) provide an additional contribution of $\mathrm{PAH}$ to Holocene sediments (Giger and Schaffner, 1977; Thompson and Eglinton, 1978a; Laflamme and Hites, 1978), most prominent in areas that receive a large urban air fallout (Farrington et al., 1977). As expected, this anthropogenic contribution of PAH shows a historical variation in accord with man's increased use of fossil fuel (Hites et al., 1977; Müller et al., 1977). The observed distributions of PAH in the three core sections analyzed differ markedly from those characteristic of fossil-fuel combustion products. In particular, the proportions of alkyl-substituted PAH in these Cretaceous sediments are significantly greater than the amounts in high-temperature combustion products (e.g., from kerosene; Lee et al., 1977) where unsubstituted PAH dominates. Combustion at lower temperatures might, however, increase the proportion of alkyl-substituted $\mathrm{PAH}$, although the combustion products from natural fires have not been investigated in detail, so that this postulation remains speculative. Alkyl homologs are present in greater amounts than their unsubstituted counterparts in both crude oils (Coleman et al., 1973) and oil shales (Youngblood and Blumer, 1975), presumably derived mainly by post-depositional aromatization. In the three core sections studied, we observed a similar dominance of alkyl-substituents over unsubstituted PAH. Unlike most crude oils, these sediments have undergone insufficient thermal treatment for components derived from the cracking of kerogen to constitute a significant proportion of the total PAH mixture, hence the requirement for an alternative source. Chemical aromatization of terpenoids, enhanced by active clay surfaces, generates PAH derivatives, and pimanthrene (1,7-dimethylphenanthrene) derived from diterpenoid acids (Simoneit, 1977; Laflamme and Hites, 1978 ) is possibly one of the alkyl-substituted phenanthrenes present. None of the core sections contains retene (1-methyl-7-isopropyl-phenanthrene), an aromatic diterpenoid derived from abietic acid, so that a major contribution of diterpenoids in the $\mathrm{PAH}$ appears unlikely. This observation argues against a major contribution of higher plant (conifer) resins to the samples investigated, although amber is present in other core sections (e.g., Section 16-2) from this site (Site 416 report, this volume).

Perylene is abundant in many Holocene sediments, suggesting a rapid generation from natural-product precursors inasmuch as it is not a significant component of anthropogenic PAH sources. Various authors have proposed early-stage production from the defunctionalization of extended quinones (Orr and Grady, 1967; Aizenshtat, 1973), a process that may be favored by rapid deposition under reducing conditions (Aizenshtat, 1973). In addition, perylene may be stabilized by IIcomplexing with transition metals (Clar, 1964). The precise mechanism of perylene formation and the stage 
at which it occurs (e.g., Laflamme and Hites, 1978) remains enigmatic at present. The relative concentration of perylene (peak 29, Figure 5; Table 7) is similar in all three core sections, which reflects the similarity of the depositional conditions. Perylene has been found in crude oils (Carruthers and Cook, 1954), but never in concentrations comparable to those of sediments. The low levels of perylene in crude oils and combustion products support the concept of its syndepositional generation.

The $\mathrm{PAH}$ distributions in all three samples appear to be natural, rather than contaminant, and represent a combination of components formed during (1) pre-, (2) syn-, and (3) postdepositional periods.

Category 1 includes a contribution of alkyl-substituted PAH, such as methylphenanthrenes, which seem to originate from incomplete combustion of organic matter, such as vegetation (e.g., forest fires). An alternative origin from the weathering of oil shales, coals, or oil seeps, etc., is possible, but other data, for example the absence of $22 \mathrm{R}$ and S diastereomeric pairs of hopanes typical of mature sediments and petroleum (Dastillung and Albrecht, 1976), argue against it. The higher alkyl homologs $\left(>\mathrm{C}_{4}\right)$ may have been lost in the three core sections during aqueous transportation as a direct result of their greater water solubility (McAuliffe, 1966; Boehm and Quinn, 1973; Eganhouse and Calder, 1976) relative to lower series members, although loss by eolian-transportation mechanisms seems more likely for combustion products.

In category 2 the major syndepositional products observed are perylene, the tentatively assigned alkyl perylenes and benzo(g,h,i)perylene (Figure 5; Table 7).

Category 3 comprises the components formed by postdepositional aromatization, including the triterpenoid-derived PAH and possibly a proportion of the unsubstituted PAH and their alkyl homologs. The thermal immaturity of the samples argues against a major contribution of PAH from kerogen breakdown.

In summary, the diversity of the PAH present in all three cores suggests that the individual components are contributed from various sources and (or) generated within the sediment during all stages of diagenesis.

\section{Nickel Porphyrins}

The mass spectrometric and HPLC data for the nickel petroporphyrins show that $C_{32}$ DPEP porphyrin (peak 15, Table 9; Figure 6) is the major compound of all three samples; we are, however, uncertain whether it is a single component or a mixture of type (positional) isomers. The former possibility would be in accord with the theory of Treibs (1936) that deoxophylloerythroetioporphyrin, $\mathrm{a} \mathrm{C}_{32}$ DPEP, is the initial porphyrin product of the defunctionalization of chlorophyll $a$.

The greater quantity of the pentamethyl diethyl $\mathrm{C}_{31}$ DPEP porphyrin in Section 416A-18-3 relative to 14-4 is unlikely to be a result of thermal maturation change because of the minor difference $(38 \mathrm{~m})$ in their subbottom depths, and the similarity of their DPEP/etio ratios. Possibly, the $\mathrm{C}_{31}$ DPEP component is formed by conversion of the chlorophyll $a$ vinyl group to a methyl group. This process may be effected by bacteria in a manner analogous to the formation of pemptoporphyrin from protoporphyrin-IX (French et al., 1964). A difference in bacterial contribution and (or) activity might therefore explain the discrepancy in the $C_{31}$ DPEP values. The possibility that the $C_{31}$ DPEP porphyrin is formed via chlorophyll $d$ seems unlikely because of the scarcity of chlorophyll $d$ in most organisms. It does occur in significant amounts in Rhodophyceae (Manning and Strain, 1943), but the distribution of other lipids argues against a major contribution of red algae to the sediment.

The absence of vanadyl porphyrins, as indicated by both mass spectrometry and electronic spectroscopy indicates sediment immaturity. The petroporphyrin concentrations and distributions of all three samples are broadly similar, as expected, considering their uniform lithology and close vertical proximity.

\section{Comparisons of Leg $\mathbf{4 8}$ and Leg 50}

The similarity of analytical procedures between investigation of Leg 48 (Barnes et al., in press) and Leg 50 samples enables comparison of the extractable lipid distributions for these two suites of samples. The main reasons for making such comparisons are: (1) to identify any similarities and differences in the lipid composition reflecting changing contributions, depositional conditions, or subsequent diagenesis, and (2) to establish points of reference for future analyses to enable the recognition of specific marker compounds.

In the two suites of samples the distributions of rearranged sterenes (as shown by $\mathrm{m} / \mathrm{e} 257$; Figure 8), their 4-methyl analogs, and the hopanoid triterpenoids, including triterpanes, triterpenes (m/e 191; Figure 8), and their derived aromatic compounds, are all remarkably similar. These similarities suggest a source component of organic matter common to both sites of deposition. Differences in the relative amounts of specific components appear to reflect changing proportions of individual contributions within this common source of organic matter rather than different diagenetic processes. This suggestion is supported by the partial similarity of $n$-alkane and $n$-alkanoic distributions.

The pristane/phytane ratios for the Leg 48 samples (avg. 1.1) are lower than those of the Leg 50 samples analyzed (avg. 1.7), suggesting that the black shale may have been deposited under lower redox potentials than the turbidite sequence (Didyk et al., 1978).

The polynuclear aromatic distribution in the Leg 50 turbidites may represent a combination of the Leg 48 perylene-dominated sample (402A-18-1) and the alkyl substituents of Sections 402A-24-1 and 402A-30-1. The variable predominance of these two components in different Leg 48 samples strengthens our belief that they originate from different sources.

One of the major differences in the lipids of the two suites of samples is their tetrapyrrole content. The higher content of nickel petroporphyrins in the turbidites may reflect different sources or a less extensive breakdown of chlorophyll prior to consolidation com- 
(a)

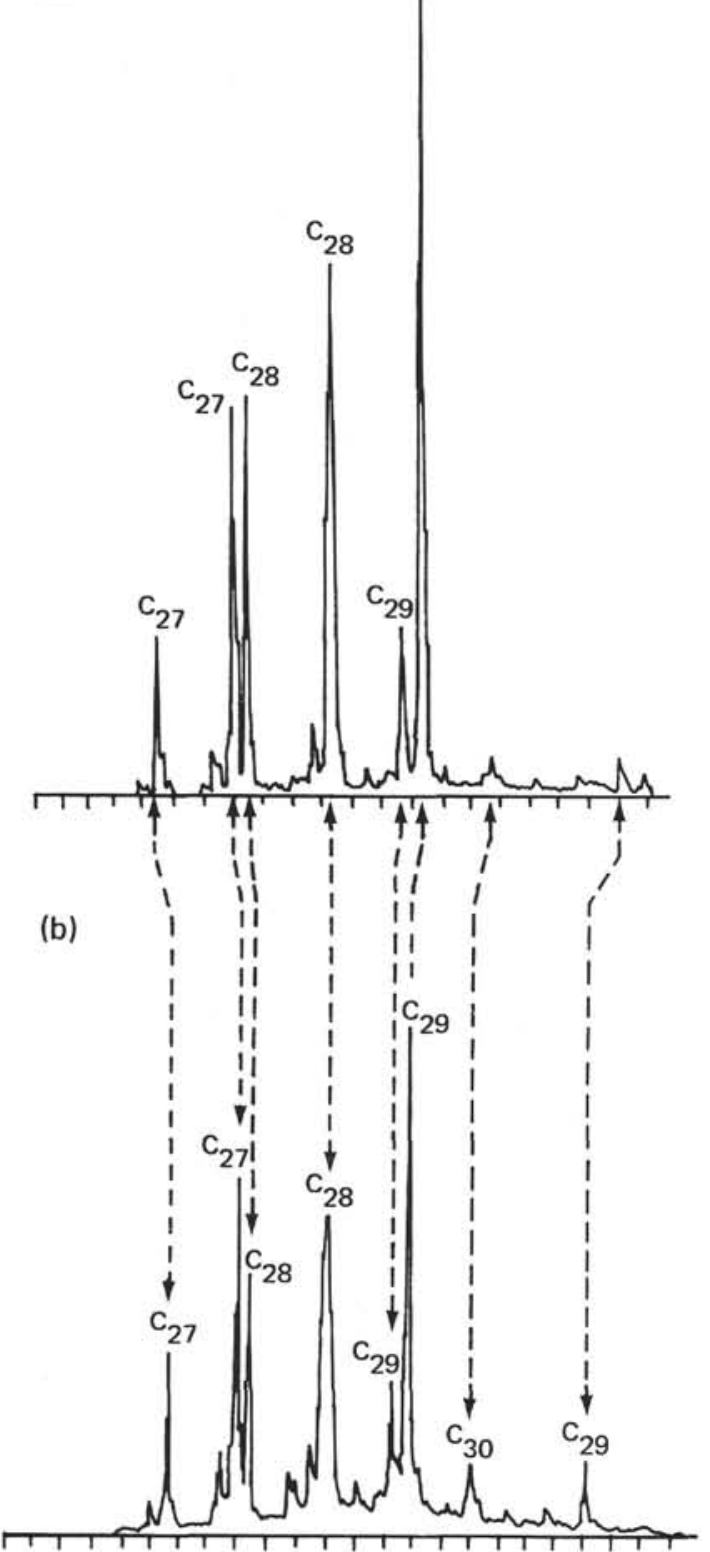

(c)

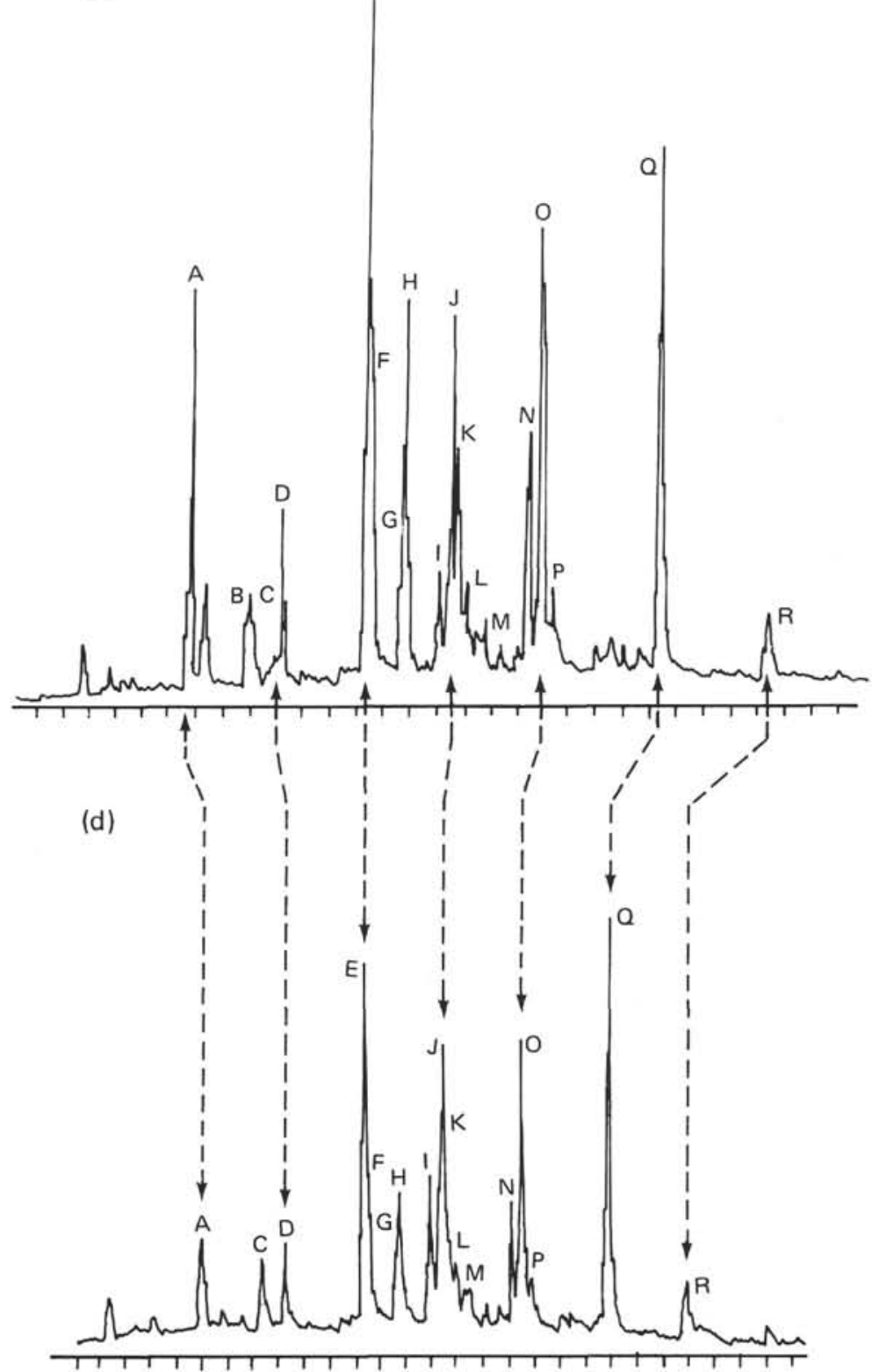

Figure 8. Qualitative comparison between the partial mass fragmentograms characteristic of two major polycyclic series from Leg 48 (upper figures, $a$ and $c$ and Leg 50 (lower figures, $b$ and $d$. $a$ and $b$ : rearranged sterenes ( $\mathrm{m} / \mathrm{e}$ 257) of Sections 402A-24-1 and 416A-18-3, respectively. Peak designations refer to the carbon number of the components. $c$ and d: triterpenoid hydrocarbons (m/e 191) of Sections 402A-24-1 and 416A-18-3, respectively. Peak letters refer to the Leg 48 assignments (Barnes et al., in press). The A to $R$ designations of Figure $8 d$ are equivalent to 1-18 in Figure 4 and Table 6.

pared to the Leg 48 black shale. In the samples from Leg 48 , the ratio of sterenes to rearranged sterenes was very low in comparison with Leg 50, particularly Section 416A-18-3. This difference may reflect the lower clay content in specific horizons of the turbidites, reducing the efficiency of the rearrangement process.

The absence of triterpanoic and triterpenoic acids in the Leg 50 samples contrasts sharply with the concentra- 
tions of Leg 48, where they occurred in significant amounts. The concentrations of triterpenoid alkanes and alkenes were also higher in Leg 48 samples. These results suggest a lower bacterial contribution to the Leg 50 samples than to the Leg 48 cores.

In summary, the similarities in the compositions of the Leg 48 and Leg 50 samples may be rationalized in terms of a common lipid contribution composing a significant part of the extractable organic matter. The organic matter in both cases includes a terrestrial component, but Leg 48 samples appear to possess a greater proportion of attributable bacterial contribution.

\section{Leg 50 Conclusions}

The similarity of the extractable lipids found in three samples of the turbidite sequence suggests fairly uniform contributions of organic matter and similar depositional conditions. Minor differences in composition may be caused by slight changes in the proportion of specific sources contributing to the three samples. The average sediment thickness of the turbidite cycles varies from core to core throughout the sequence (Table 1), so that each sample interval contains incomplete cycles. Because the turbidites are graded, the three core sections are probably biased toward particular grain-size fractions. Lipids from specific sources are known to be concentrated in discrete grain-size fractions (Thompson and Eglinton, 1978b); hence the lipid distributions may, in part, reflect the particle-size differences rather than changing sources of the organic matter. The limited range of parallel lipid analyses precludes detailed assignment of components and diagenetic history; however, we can recognize both terrestrial and algal contributions of organic matter, whereas the minor differences in depth between the samples (Table 1) explain the absence of any prominent differences in their state of diagenesis. The maturity of the three core sections, on the evidence of the absence of rearranged steranes and $22 \mathrm{R}$ and $\mathrm{S}$ diastereomeric hopane pairs is similar to the Messel shale (e.g., Ensminger, 1977; Wardroper et al., 1977; Ensminger et al., 1978), thought to have been subjected to a maximum temperature of $40^{\circ} \mathrm{C}$ (Matthes, 1968). Assuming a geothermal gradient of about $2-4^{\circ} \mathrm{C} / \mathrm{hm}$ for the Moroccan basin, a depth of burial of 1362 meters (Table 1) would correspond to a temperature of about $30^{\circ}$ to $55^{\circ} \mathrm{C}$.

\section{ACKNOWLEDGMENTS}

We thank the Natural Environment Research Council (GR3/2951) for support and the National Aeronautics and Space Administration (subcontract from NGL 05-003-003) and the Nuffield Foundation for additional funding. J. McEvoy and S. C. Brassell acknowledge Research Studentships from the Natural Environment Research Council. J. K. Volkman acknowledges support from the Natural Environment Research Council (GR3/3419). We also wish to thank Mr. A.M.K. Wardroper for information on mass spectral assignments, Mrs. A. P. Gowar for assistance with GC-MS analyses, and Dr. T. W. Griffiths for help with electronic spectrometry. We are grateful to Mr. G. C. Speers and Mr. T. Doran of British Petroleum for access to their preliminary petrographic data.

\section{REFERENCES}

Aizenshtat, Z., 1973. Perylene and its geochemical significance, Geochim. Cosmochim. Acta, v. 37, p. 559-567.

Baker, E. W., Corwin, A. H., Klespe, E., and Wei, P. E., 1968. Deoxophylloerythroetioporphyrin, J. Org. Chem., v. 33, p. 3144-3148.

Baker, E. W. and Palmer, S. E., in press. Tetrapyrrole pigments in Cretaceous sediments from the Bay of Biscay, DSDP Leg 48, Hole 402A. In Montadert, L., Roberts D. G., et al., Initial Reports of the Deep Sea Drilling Project, v. 48: Washington (U.S. Government Printing Office).

Baker, E. W., Palmer, S. E., and Huang, W. Y., 1978. Early and intermediate chlorophyll diagenesis of Black Sea sediments: Sites 379, 380, and 381. In Ross, D., Neprochnov, Y., et al., Initial Reports of the Deep Sea Drilling Project, v. 42, Part 2: Washington (U.S. Government Printing Office), p. 707-715.

Barnes, P. J., Brassell, S. C., Comet, P. A., Eglinton, G., McEvoy, J., Maxwell, J. R., Wardroper, A.M.K., and Volkman, J. K., in press. Preliminary lipid analyses of core sections 18, 24, and 30 from Hole 402A. In Montadert, L., Roberts, D. G., et al., Initial Reports of the Deep Sea Drilling Project, v. 48: Washington (U.S. Government Printing Office).

Blumer, M., 1965. Organic pigments: their long term fate, Science, v. 149 , p. $722-726$.

Blumer, M. and Youngblood, W. W., 1975. Polycyclic aromatic hydrocarbons in soils and Recent sediments, Science, v. 188 , p. $53-55$.

Boehm, P. D. and Quinn, J. G., 1973. Solubilization of hydrocarbons by the dissolved organic matter in sea water, Geochim. Cosmochim. Acta, v. 37, p. 2459-2477.

Boon, J. J., De Leeuw, J. W., Van der Hoek, G. J., and Vosjan, J. H., 1977. Science and taxonomic value of iso and anteiso monoenoic fatty acids and branched $\beta$-hydroxy acids in Desulfovibrio desulfuricans, J. Bact., v. 129, p. 1183-1191.

Brooks, B. T., 1948. Role of surface-active catalysts in formation of petroleum, Am. Assoc. Petrol. Geol. Bull., v. 32, p. 2269-2286.

Buchler, J. W. and Puppe, L., 1970. Metallchelate des $\propto \bullet \gamma-$ Dimethyl- $\propto \bullet \gamma$ dihydro-octäathylporphins durch reduzierende Methylierung von Octăathylporphinato-zink, Ann., v. 740 , p. $142-163$.

Cardoso, J. N., Wardroper, A.M.K., Watts, C. D., Barnes, P. J., Maxwell, J. R., Eglinton, G., Mound, D. G., and Speers, G. C., 1978. Preliminary organic geochemical analyses: Site 391, Leg 44 of the Deep Sea Drilling Project. In Benson, W. E., Sheridan, R. E., et al., Initial Reports of the Deep Sea Drilling Project, v. 44: Washington (U.S. Government Printing Office), p. 617-624.

Carruthers, W. and Cook, J. W., 1954. The constituents of high-boiling petroleum distillates: preliminary studies, $J$. Chem. Soc., p. 2047-2052.

Clar, E., 1964. Polycyclic hydrocarbons: London (Academic Press Inc.), v. II.

Coleman, H. J., Doley, J. E., Hirsch, D. E., and Thompson, C. J., 1973. Compositional studies of a high boiling, $370^{\circ}-535^{\circ} \mathrm{C}$, distillate from Prudhoe Bay, Alaska, crude oil, Anal. Chem., v. 45, p. 1724-1730.

Dastillung, M. and Albrecht, P., 1976. Molecular test for oil pollution in surface sediments, Mar. Pollut. Bull., v. 7, p. 13-15.

1977. $\Delta^{2}$ Sterenes as diagenetic intermediates in sediments, Nature, v. 269 , p. 678-679. 
Didyk, B. M., Simoneit, B.R.T., Brassell, S. C., and Eglinton, G., 1978. Organic geochemical indicators of palaeoenvironmental conditions of sedimentation, Nature, v. 272, p. 216-222.

Eganhouse, R. P. and Calder, J. A., 1976. The solubility of medium molecular weight aromatic hydrocarbons and the effects of hydrocarbon co-solutes and salinity, Geochim. Cosmochim. Acta, v. 40, p. 555-561.

Eglinton, G. and Hamilton, R. J., 1967. Leaf epicuticular waxes, Science, v. 156, p. 1322-1335.

Eglinton, G., HajIbrahim, S. K., Maxwell, J. R., Quirke, J.M.E., Shaw, G. J., Volkman, J. K., and Wardroper, A.M.K., 1978. Lipids of aquatic sediments, Recent and ancient, Proc. Roy. Soc. series A.

Ensminger, A., 1977. Evolution de composes polycycliques sedimentaires, Ph.D. thesis, Université Louis Pasteur, Strasbourg.

Ensminger, A., Joly, G., and Albrecht, P., 1978. Rearranged steranes in sediments and crude oils, Tetrahedron Lett., p. $1575-1578$.

Farrington, J. W., Frew, N. M., Gschwend, P. M., and Tripp, B. W., 1977. Hydrocarbons in cores of northwestern Atlantic coastal and continental margin sediments, Estuarine Coast. Mar. Sci., v. 5, p. $793-808$.

French, J. M., England, M. T., Lines, J., and Thonger, E., 1964. Separation of ether extractable fecal porphyrins by counter current distribution, Arch. Biochem. Biophys., v. 107, p. $404-418$.

Frenkel, M. and Heller-Kallai, L., 1978. Aromatization of limonene - a geochemical model, Org. Geochem., v. 1, p. 3-9.

Giger, W. and Schaffner, C., 1977. Aliphatic, olefinic and aromatic hydrocarbons in recent sediments of a highly eutrophic lake: In Campos, R. and Goni, J. (Eds.), Advances in organic geochemistry 1975: Madrid (ENADIMSA), p. 375-391.

Greiner, A. Ch., Spyckerelle, C. S., and Albrecht, P., 1976. Aromatic hydrocarbons from geological sources - I: New naturally occurring phenanthrene and chrysene derivatives, Tetrahedron, v. 32, p. 257-260.

HajIbrahim, S. K., 1978. Application of petroporphyrins to the maturation, migration and origin of crude oils, Ph.D. thesis, University of Bristol.

HajIbrahim, S. K., Tibbetts, P.J.C., Watts, C. D., Maxwell, J. R., Eglinton, G., Colin, H., and Guiochon, G., 1978. Analysis of carotenoid and porphyrin pigments of geochemical interest by high-performance liquid chromatography, Anal. Chem., v. 50, p. 549-553.

Hites, R. A., Laflamme, R. E., and Farrington, J. W., 1977. Polycyclic aromatic hydrocarbons in recent sediments: the historical record, Science, v. 198, p. 829-831.

Huang, W-Y. and Meinschein, W. G., 1976. Sterols as source indicators of organic materials in sediments, Geochim. Cosmochim. Acta, v. 40, p. 323-330.

Laflamme, R. E. and Hites, R. A., 1978. The global distribution of polycyclic aromatic hydrocarbons in recent sediments, Geochim. Cosmochim. Acta, v. 42, p. 289-303.

Lee, M. L., Novotny, M., and Bartle, K. D., 1976. Gas chromatography/mass spectrometric and nuclear magnetic resonance determination of polynuclear aromatic hydrocarbons in airborne particulates, Anal. Chem., v. 48, p. 1566-1572.

Lee, M. L., Prado, G. P., Howard, J. B., and Hites, R. A., 1977. Source identification of urban airborne polycyclic aromatic hydrocarbons by gas chromatographic mass spectrometry and high resolution mass spectrometry, Biomed. Mass Spec., v. 4, p. 182-186.

Mair, B. J., 1964. Terpenoids, fatty acids and alcohols as source materials for petroleum hydrocarbons, Geochim. Cosmochim. Acta, v. 28, p. 1303-1321.

Manning, W. M. and Strain, H. H., 1943. Chlorophyll $d$, a green pigment of red algae, J. Biol. Chem., v. 151, p. 1-19.

Matthes, G., 1968. Les couches Éocènes dans la région du Fossé Rhénan septentrional, Mem. Bureau Rech. Géol. Min., v. 58, p. 327-337.

McAuliffe, C., 1966. Solubility in water of paraffin, cycloparaffin, olefin, acetylene, cycloolefin, and aromatic hydrocarbons, J. Phys. Chem., v. 70, p. 1267-1275.

Müller, G., Grimer, G., and Boehnke, H., 1977. Sedimentary record of heavy metals and polycyclic aromatic hydrocarbons in Lake Constance, Naturwissenschaften, v. 64, p. $427-431$.

Orr, W. L. and Grady, J. R., 1967. Perylene in basin sediments off southern California, Geochim. Cosmochim. Acta, v. 31, p. 1201-1209.

Rubinstein, I., Sieskind, O., and Albrecht, P., 1975. Rearranged sterenes in a shale: occurrence and simulated formation, J. Chem. Soc. Perkin I, p. 1833-1836.

Shaw, N., 1974. Lipid composition as a guide to the classification of bacteria: In Perlman, D. (Ed.), Advances in applied microbiology: New York (Academic Press, Inc.), v. 17, p. 63-109.

Simoneit, B. R. T., 1977. Diterpenoid components and other lipids in deep-sea sediments and their geological significance, Geochim. Cosmochim. Acta, v. 41, p. 463-476.

Spyckerelle, C., 1975. Constituents aromatiques de sédiments, Ph.D. thesis, Universite Louis Pasteur, Strasbourg.

Thompson, S. and Eglinton, G., 1978a. Composition and sources of pollutant hydrocarbons in the Severn Estuary, Mar. Pollut. Bull., v. 9, p. 133-136.

$1978 \mathrm{~b}$. The fractionation of a Recent sediment for organic geochemical analysis, Geochim. Cosmochim. Acta, v. 42 , p. $199-207$.

Tissier, M. J. and Spyckerelle, C., 1977. Hydrocarbures polyaromatiques des sediments, Orgon I, Mer de Norvège: Paris (Éditions du CNRS), p. 229-236.

Treibs, A., 1936. Chlorophyll und Hamin Mineralstoffen, Angew. Chem., v. 49, p. 682-686.

Van de Meent, D., Maters, W. L., De Leeuw, J. W., and Schenck, P. A., 1977. Formation of artifacts in sediments upon freeze drying, Org. Geochem., v. 1, p. 7-9.

Van Dorsselaer, A., Ensminger, A., Spyckerelle, C., Dastillung, M., Sieskind, O., Arpino, P., Albrecht, P., Ourisson, G., Brooks, P. W., Gaskell, S. J., Kimble, B. J., Philp, R. P., Maxwell, J. R., and Eglinton, G., 1974. Degraded and extended hopane derivatives $\left(\mathrm{C}_{27}\right.$ to $\left.\mathrm{C}_{35}\right)$ as ubiquitous geochemical markers, Tetrahedron Lett., p. 1349 1352.

Wardroper, A. M. K., Brooks, P. W., Humberston, M. J., Maxwell, J. R., 1977. Analysis of steranes and triterpanes in geolipid extracts by automatic classification of mass spectra, Geochim. Cosmochim. Acta, v. 41, p. 499-509.

Youngblood, W. W. and Blumer, M., 1975. Polycyclic aromatic hydrocarbons in the environment: homologous series in soils and recent marine sediments, Geochim. Cosmochim. Acta, v. 39, p. 1303-1314. 
APPENDIX 2
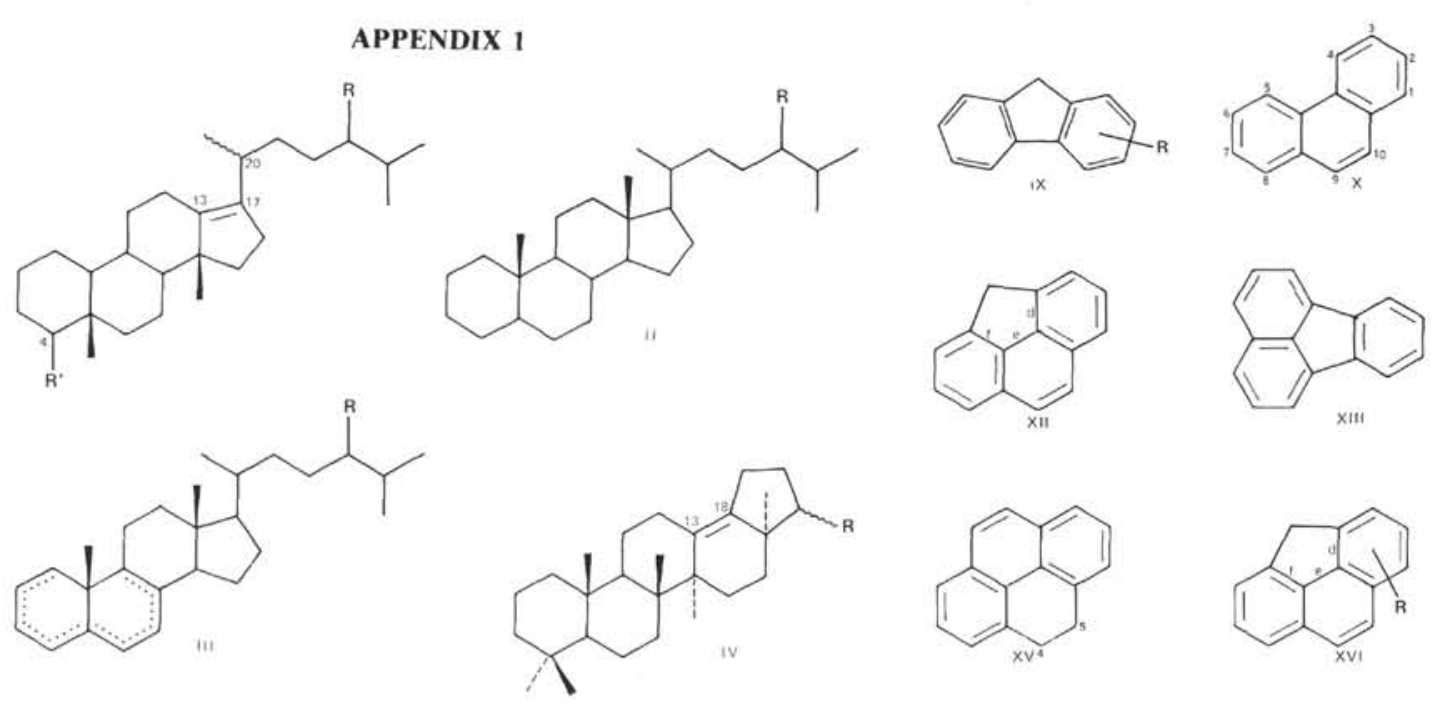<smiles>c1ccc2c(c1)ccc1ccccc12</smiles>
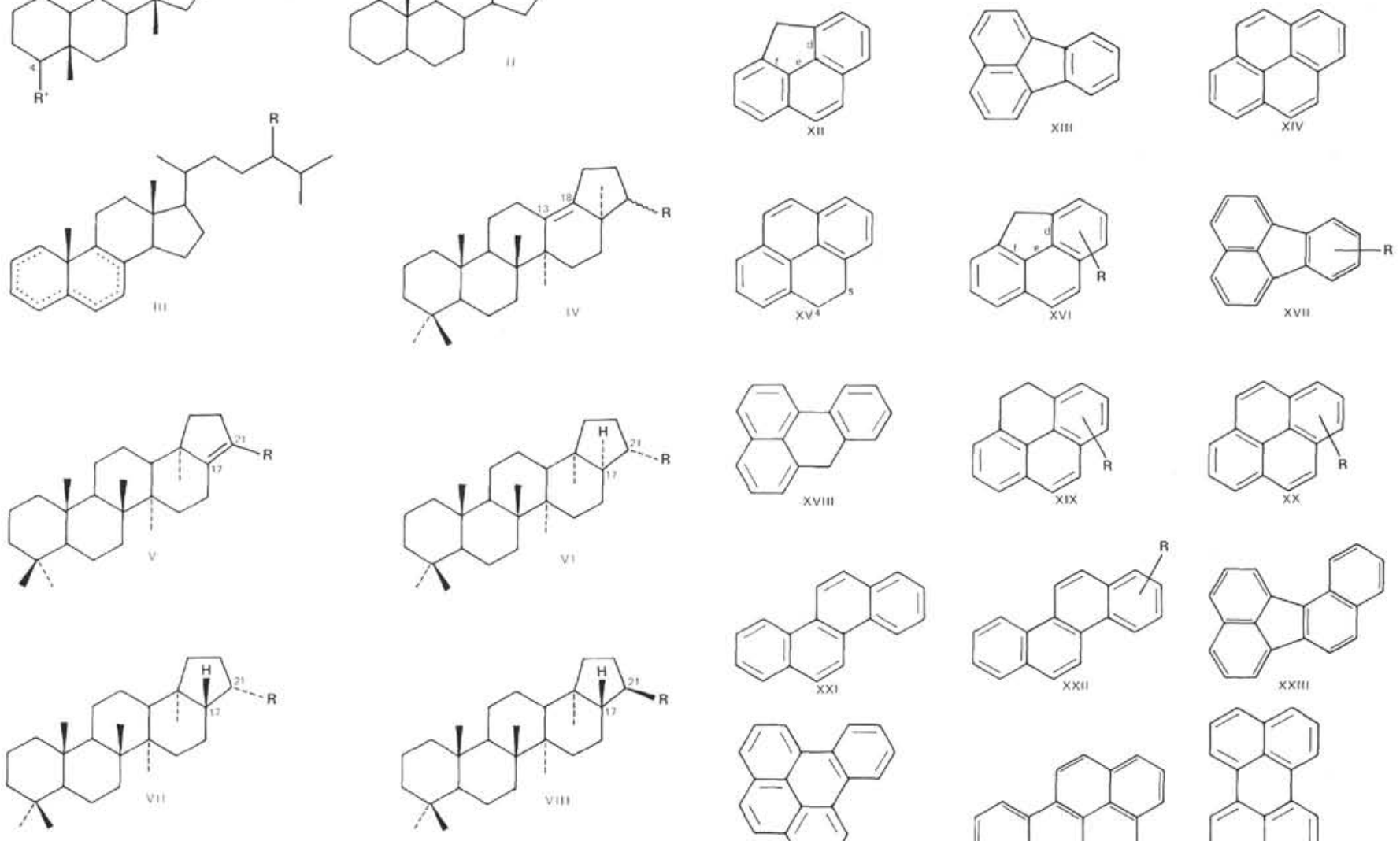<smiles>c1ccc2c(c1)ccc1c3ccccc3ccc21</smiles><smiles>c1ccc2c(c1)ccc1c3ccccc3ccc21</smiles><smiles></smiles><smiles>c1cc2c3c-2cccc3ccc2cccc3c2=c2c(c1)cccc23</smiles><smiles>C1=Cc2cccc3ccc4c1cc1ccccc1c4c23</smiles><smiles></smiles> 
S. C. BRASSELL ET AL.

APPENDIX 3
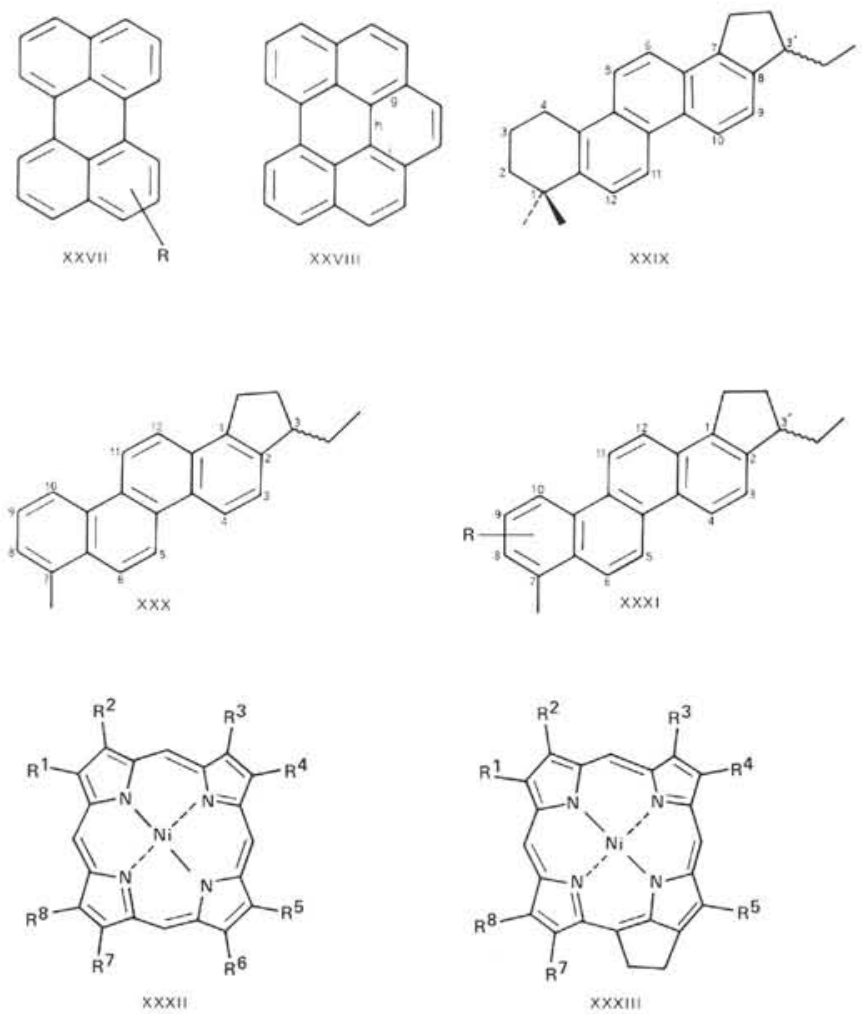